\title{
Impact of HONO on global atmospheric chemistry calculated with an empirical parameterization in the EMAC model
}

\author{
Y. F. Elshorbany ${ }^{1,2}$, B. Steil ${ }^{1}$, C. Brühl ${ }^{1}$, and J. Lelieveld ${ }^{1,3,4}$ \\ ${ }^{1}$ Max-Plank Institute for Chemistry, Atmospheric Chemistry Department, Mainz, Germany \\ ${ }^{2}$ National Research Center, Environmental Sciences Research Division, Cairo, Egypt \\ ${ }^{3}$ The Cyprus Institute, Nicosia, Cyprus \\ ${ }^{4}$ King Saud University, Riyadh, Saudi Arabia
}

Correspondence to: Y. F. Elshorbany (yasin.elshorbany@mpic.de)

Received: 23 April 2012 - Published in Atmos. Chem. Phys. Discuss.: 23 May 2012

Revised: 27 September 2012 - Accepted: 1 October 2012 - Published: 30 October 2012

\begin{abstract}
The photolysis of HONO is important for the atmospheric $\mathrm{HO}_{\mathrm{x}}\left(\mathrm{OH}+\mathrm{HO}_{2}\right)$ radical budget and ozone formation, especially in polluted air. Nevertheless, owing to the incomplete knowledge of HONO sources, realistic HONO mechanisms have not yet been implemented in global models. We investigated measurement data sets from 15 field measurement campaigns conducted in different countries worldwide. It appears that the $\mathrm{HONO} / \mathrm{NO}_{\mathrm{x}}$ ratio is a good proxy predictor for HONO mixing ratios under different atmospheric conditions. From the robust relationship between HONO and $\mathrm{NO}_{\mathrm{x}}$, a representative mean $\mathrm{HONO} / \mathrm{NO}_{\mathrm{x}}$ ratio of 0.02 has been derived. Using a global chemistry-climate model and employing this $\mathrm{HONO} / \mathrm{NO}_{\mathrm{x}}$ ratio, realistic $\mathrm{HONO}$ levels are simulated, being about one order of magnitude higher than the reference calculations that only consider the reaction $\mathrm{OH}+\mathrm{NO} \rightarrow \mathrm{HONO}$. The resulting enhancement of HONO significantly impacts $\mathrm{HO}_{\mathrm{x}}$ levels and photo-oxidation products (e.g, $\left.\mathrm{O}_{3}, \mathrm{PAN}\right)$, mainly in polluted regions. Furthermore, the relative enhancements in $\mathrm{OH}$ and secondary products are higher in winter than in summer, thus enhancing the oxidation capacity in polluted regions, especially in winter when other photolytic $\mathrm{OH}$ sources are of minor importance. Our results underscore the need to improve the understanding of HONO chemistry and its representation in atmospheric models.
\end{abstract}

\section{Introduction}

Since three decades, nitrous acid (HONO) photolysis has been shown to be an important source of hydroxyl $(\mathrm{OH})$ radicals, especially during the early morning when other sources are of minor importance (Perner and Platt, 1979; Harris et al., 1982). Recently, HONO photolysis was reported to contribute more strongly to daytime primary $\mathrm{OH}$ production than $\mathrm{O}_{3}$ photolysis, both under urban and rural conditions (Elshorbany et al., 2009a; Sörgel et al., 2011a, respectively). It has been demonstrated that HONO photolysis can be a major $\mathrm{OH}$ initiation source under high $\mathrm{NO}_{\mathrm{x}}$ (e.g., Kleffmann et al., 2007; Elshorbany et al., 2009a, 2010a; Ren et al., 2006; Dusanter et al., 2009) as well as low $\mathrm{NO}_{\mathrm{x}}$ conditions (e.g., Kleffmann et al., 2005; Elshorbany et al., 2012, Sörgel et al., 2011a). OH radicals constitute the major oxidant of the atmosphere, initiating the removal of most reactive gases (i.e. regulating the self-cleaning capacity of the atmosphere), though also lead to the formation of secondary products such as $\mathrm{O}_{3}$ and PAN, which can be harmful for human health. The $\mathrm{OH}$ oxidation of volatile organic compound (VOC) contributes to the formation of aerosol particles, affecting air quality and climate. HONO is also an important ingredient of the strongly anthropogenically perturbed global nitrogen cycle, which indirectly influences climate change (Kumala and Petäjä, 2011).

Owing to the thus far incomplete knowledge of HONO sources, in particular during daytime, it was not yet possible to simulate realistic HONO levels using global models. Li et al. (2010), Zhang et al. (2011) and Czader et al. (2012) 
have shown that additional HONO sources are required to match measured HONO mixing ratios; for some regions tenfold mismatches have been found based on the known gas phase $\mathrm{HONO}$ formation only (i.e., $\mathrm{OH}+\mathrm{NO} \rightarrow \mathrm{HONO}$ ). $\mathrm{Li}$ et al. (2011) and Goncalves et al. (2012) showed that modelled HONO was consistently lower than observations, even when the most effective recently suggested formation mechanisms were considered. This underestimation of HONO by models may be expected to impact the simulated $\mathrm{HO}_{\mathrm{x}}$ and $\mathrm{O}_{3}$ budgets as well as other secondary products.

Several HONO sources have been identified in the laboratory (e.g., Zhou et al., 2003; George et al., 2005; Stemmler et al., 2006, 2007; Bejan et al., 2006; Li et al., 2008, Gustafsson et al., 2006; Ndour et al., 2008; Su et al., 2011), yet these sources cannot account for the HONO levels observed during daytime (Elshorbany et al., 2010b; Su et al., 2011; Czader et al., 2012). While the heterogeneous conversion of $\mathrm{NO}_{2}$ on humid surfaces (Finlayson-Pitts et al., 2003) in the dark is commonly accepted as the dominant HONO source during the night (Alicke et al., 2002), the exact mechanism is still unclear. For daytime HONO sources, five photochemical mechanisms were recently identified. Three of them dominate under high- $\mathrm{NO}_{\mathrm{x}}$ urban conditions, i.e., heterogeneous conversion of gaseous $\mathrm{NO}_{2}$ on photosensitized solid surface organic compounds (George et al., 2005; Stemmler et al., 2006), photocatalytic conversion of $\mathrm{NO}_{2}$ on $\mathrm{TiO}_{2}$ (Gustafsson et al., 2006; Ndour et al., 2008) and the photolysis of gaseous nitro-aromatic compounds (Bejan et al., 2006), which are expected to correlate well with $j\left(\mathrm{NO}_{2}\right)$. Under low- $\mathrm{NO}_{\mathrm{x}}$ rural conditions, the photolysis of nitric acid (Zhou et al., 2003, 2011) adsorbed on solid surfaces (including vegetation) may dominate and is expected to primarily correlate with $j\left(\mathrm{O}^{1} \mathrm{D}\right)$, related to the much lower wavelength range of nitric acid photolysis than $j\left(\mathrm{NO}_{2}\right)$. Su et al. (2011) showed that HONO can also be emitted from soils, being a function of temperature (i.e, light independent). This source may be important in tropical forested regions. Sörgel et al. (2011a) showed that unknown HONO daytime sources, normalized with $\mathrm{NO}_{2}$ mixing ratios have a clear dependency on $j\left(\mathrm{NO}_{2}\right)$. Recently, Czader et al. (2012) also showed that photo-induced conversion of $\mathrm{NO}_{2}$ on organic surfaces is a strong daytime $\mathrm{HONO}$ source.

In addition to the incomplete knowledge about daytime HONO chemistry, most of the thus far identified HONO sources are generally also associated with large uncertainty as the mechanisms and controlling parameters are only partly understood (Kleffmann, 2007; Li et al., 2010; Czader et a., 2012; Goncalves et al., 2012). Consequently, several recent attempts to simulate HONO formation were based on the modulation of the model parameters (i.e., via several assumptions and simplifications) to match the measurements in individual studies (e.g., Li et al., 2010; Czader et al., 2012; Goncalves et al., 2012). For example, Czader et al. (2012) simulated HONO using an approach adopted by $\mathrm{Li}$ et al. (2010), for which a daytime HONO source with a relatively large uptake coefficient was employed based on variable threshold values of light intensity. However, Czader et al. (2012) obtained unrealistically high HONO concentrations and therefore used the same uptake coefficient but scaled by a different and constant factor to match the measured HONO. In contrast, Goncalves et al. (2012) obtained about three orders of magnitude lower production rates of HONO when using the approach adopted by Li et al. (2010) and reverted to another approach, more suitable to the studied area. Unfortunately, this approach to match measurements cannot be implemented in global models, as each region would need its specific parameterization. Thus, a more general approach is needed to calculate more realistic HONO levels on a global scale.

A common factor between the known major day- and nighttime sources is that they are generally surface-based (except the gas phase photolysis of nitro-aromatic compounds). Indeed, such HONO sources contribute a major fraction to the measured HONO levels (Harrison and Kitto, 1994; Stutz et al., 2002; Veitel, 2002; Kleffmann et al., 2003; Zhang et al., 2009; Sörgel et al., 2011b; Wong et al., 2011) and consequently the dispersion into the atmosphere is a function of turbulent mixing (Sörgel et al. 2011b). This was first proposed by Febo et al. (1996) based on Radon measurements, a species emitted almost exclusively from the ground. Veitel (2002) also showed that HONO correlates linearly with Radon with highest values reported in winter. In addition, both, ground- and aircraft-based gradient measurements showed that HONO mixing ratios near to the ground follow a steep gradient during stable conditions (Veitel, 2002; Zhang et al., 2009, respectively). Thus, HONO mixing ratios appear to be controlled by the surface area in a mixed volume of air $(\mathrm{s} / \mathrm{v})$, and the changes can often be accounted for by scaling $\mathrm{HONO}$ to $\mathrm{NO}_{2}$ or $\mathrm{NO}_{\mathrm{x}}$ (Sörgel et al. 2011b, and references therein). Similarly, Zhang et al. (2011) showed that the spatial distribution of simulated HONO during day- and nighttime is generally consistent with the $\mathrm{NO}_{\mathrm{x}}$ emission pattern. Kleffmann (2007) concluded that the $\mathrm{HONO} / \mathrm{NO}_{\mathrm{x}}$ ratio is a reasonable measure of $\mathrm{HONO}$ as it takes into account the dilution of trace gases during transport, after being emitted or formed at the ground. Several previous studies indicated the $\mathrm{HONO} / \mathrm{NO}_{\mathrm{x}}$ ratio as a proxy for HONO formation under rural (e.g. Acker et al., 2006; Elshorbany et al., 2012; Sörgel et al., 2011b), remote (e.g. Kleffmann and Wiesen, 2008) and urban conditions (e.g. Elshorbany et al., 2009a, 2010a). Furthermore, Villena et al. (2011a) showed that the HONO/NO ratio and its daytime maximum are independent of altitude. Thus, the $\mathrm{HONO} / \mathrm{NO}_{\mathrm{x}}$ ratio may be a practicable metric to help predict $\mathrm{HONO}$ in the atmosphere.

In this study, data sets from 15 different field measurement campaigns around the globe are investigated, confirming that the $\mathrm{HONO} / \mathrm{NO}_{\mathrm{x}}$ ratio is a good proxy predictor of the HONO mixing ratio for use in global models. The impacts of simulated HONO levels on the levels of oxidants $\left(\mathrm{OH}, \mathrm{O}_{3}, \mathrm{PAN}\right.$, 
Table 1. Summary of the field measurement data sets used.

\begin{tabular}{|c|c|c|c|c|c|c|c|c|c|c|}
\hline \multirow[t]{2}{*}{ campaign } & \multirow[t]{2}{*}{ location } & \multirow[t]{2}{*}{ latitude, longitude } & \multirow[t]{2}{*}{ measurements period } & \multicolumn{2}{|c|}{ HONO [ppbv] } & \multicolumn{2}{|c|}{$\mathrm{NO}_{2}$ [ppbv] } & \multicolumn{2}{|c|}{$\mathrm{NO}_{\mathrm{x}}[\mathrm{ppbv}]$} & \multirow[t]{2}{*}{ reference } \\
\hline & & & & $24 \mathrm{~h}$ & daytime & $24 \mathrm{~h}$ & daytime & $24 \mathrm{~h}$ & daytime & \\
\hline HOxComp & Jülich, Germany & $50^{\circ} 54^{\circ} \mathrm{N}, 06^{\circ} 24^{\circ} \mathrm{E}$ & June-July 2005 & 0.22 & 0.12 & 4.26 & 2.89 & 4.79 & 3.66 & Elshorbany et al. (2012) \\
\hline Santiago_S & Santiago de Chile & $33^{\circ} 26^{\circ} \mathrm{S}, 70^{\circ} 40^{\circ} \mathrm{W}$ & 8-20 March, 2005 & 2.39 & 1.90 & 23.84 & 18.53 & 80.63 & 49.73 & Elshorbany et al. (2009) \\
\hline Santiago_W & Santiago de Chile & $33^{\circ} 26^{\circ} \mathrm{S}, 70^{\circ} 40^{\circ} \mathrm{W}$ & 25 May-6 June, 2005 & 5.17 & 3.25 & 48.33 & 69.59 & 262.72 & 140.22 & Elshorbany et al. (2010b) \\
\hline Santiago_3 $(6 \mathrm{~m})$ & Santiago de Chile & $33^{\circ} 26^{\circ} \mathrm{S}, 70^{\circ} 40^{\circ} \mathrm{W}$ & November 2009 & 1.44 & 1.40 & 35.98 & 39.50 & 74.24 & 81.49 & Villena et al. (2011a) \\
\hline Santiago_21 (53 m) & Santiago de Chile & $33^{\circ} 26^{\circ} \mathrm{S}, 70^{\circ} 40^{\circ} \mathrm{W}$ & November 2009 & 1.00 & 0.85 & 31.01 & 31.93 & 46.82 & 49.80 & Villena et al. (2011a) \\
\hline DOMINO & El Arenosillo, Spain & $37^{\circ} 05^{\circ} \mathrm{N}, 06^{\circ} 44^{\circ} \mathrm{W}$ & November, December, 2008 & 0.08 & 0.03 & 1.80 & 1.09 & 1.88 & 1.48 & Sörgel et al. (2011) \\
\hline PMTACS-NY & New York, USA & $40^{\circ} 44^{\circ} \mathrm{N}, 73^{\circ} 49^{\circ} \mathrm{W}$ & July-August 2001 & 0.66 & 0.46 & 26.44 & 21.51 & 31.06 & 28.29 & Ren et al. (2003) \\
\hline MCMA-2006 & New Mexico, USA & $19^{\circ} 25^{\circ} \mathrm{N}, 99^{\circ} 8^{\circ} \mathrm{W}$ & 14-31 March, 2006 & 1.03 & 0.35 & $\mathrm{n} / \mathrm{a}$ & 28.40 & $\mathrm{n} / \mathrm{a}$ & 44.80 & Dusanter et al. (2009) \\
\hline LOOP/PIPAPO & Milan, Italy & $45^{\circ} 32^{\circ} \mathrm{N}, 09^{\circ} 12^{\circ} \mathrm{E}$ & May-June 1998 & 0.53 & 0.14 & 25.75 & 18.30 & 70.45 & 23.40 & Alicke et al. (2002) \\
\hline NITROCAT & Rome, Italy & $22^{\circ} 36^{\circ} \mathrm{N}, 113^{\circ} 35^{\circ} \mathrm{E}$ & May-Jun 2001 & 0.58 & 0.15 & 15.60 & 4.00 & 27.70 & 4.20 & Acker et al. (2006) \\
\hline PRIDE_PRD2004 & Xinken, China & $41^{\circ} 55^{\circ} \mathrm{N}, 12^{\circ} 30^{\circ} \mathrm{E}$ & 13 October-2 November & 1.05 & 0.80 & 32.40 & 30.00 & 38.90 & 40.00 & Su et al. (2008) \\
\hline Kathmandu & Kathmandu, Nepal & $27^{\circ} 43^{\circ} \mathrm{N}, 85^{\circ} 21^{\circ} \mathrm{E}$ & January-February, 2003 & 1.05 & 0.35 & 13.25 & 8.60 & 16.55 & 13.00 & Yu et al. (2009) \\
\hline BERLIOZ & Pabstthum, Geremany & $52^{\circ} 51^{\circ} \mathrm{N}, 12^{\circ} 56^{\circ} \mathrm{E}$ & July-August 1998 & 0.20 & 0.07 & 3.25 & 3.60 & 3.95 & 4.60 & Alicke et al. (2003) \\
\hline Yufa & Yufa, China & $39^{\circ} 30^{\circ} \mathrm{N}, 116^{\circ} 17^{\circ} \mathrm{E}$ & July-August 2006 & 0.66 & 0.43 & 11.10 & 8.00 & 13.85 & 9.40 & Li et al. $(2012)^{*}$ \\
\hline PRIDE-PRD2006 & Back Garden, China & $23^{\circ} 30^{\circ} \mathrm{N}, 113^{\circ} 1^{\circ} \mathrm{E}$ & June 2006 & 0.60 & 0.24 & 10.50 & 4.50 & 13.20 & 5.50 & Li et al. (2012) \\
\hline
\end{tabular}

* no reference could be found and data were adopted from Li et al. (2012).

etc.) are determined using an atmospheric chemistry-climate model.

\section{Methodology}

\subsection{Model description}

The applied modelling system is based on the ECHAM5 general circulation model (Roeckner et al., 2006) and the Modular Earth Submodel System (MESSy, Jöckel et al., 2005) to simulate the meteorology and atmospheric chemistry. The ECHAM5/MESSy Atmospheric Chemistry (EMAC) system is a coupled lower-middle atmospheric chemistry general circulation model (AC-GCM), which has been extensively evaluated (e.g., Jöckel et al., 2006; Lelieveld et al., 2007; Tost et al., 2007; Pozzer et al., 2008; 2010, 2012; Brühl et al., 2012). The model structure and setup have been described by Jöckel et al. (2006) and only a brief description is given here.

Atmospheric chemical reactions are incorporated in the model through the module MECCA1 (Sander et al., 2005), including the Mainz Isoprene Mechanism, version 2 (MIM2, Pöschl et al., 2000; von Kuhlmann et al., 2004; Taraborrelli et al., 2009). To study the effects of changes in the chemistry while avoiding possible feedbacks of radiatively active gases and aerosols through the meteorology, the radiation scheme has been decoupled, and the model is used in the atmospheric chemistry-transport mode. The radiation code in EMAC therefore uses an ozone climatology (Fortuin and Kelder, 1998), fixed vertical profiles for $\mathrm{CH}_{4}, \mathrm{~N}_{2} \mathrm{O}$ and CFCs and constant mixing ratios of $\mathrm{CO}_{2}$. The reference run (Base) has been performed for the year 2005 in T42L31 resolution (i.e., with a triangular truncation at wave number 42 for the spectral core of ECHAM5, and with 31 levels on a hybridpressure grid in the vertical, reaching up to $10 \mathrm{hPa}$ ). The T42 resolution corresponds to a quadratic Gaussian grid of approximately $2.8^{\circ} \times 2.8^{\circ}$ in latitude and longitude. To simulate realistic synoptic conditions, we applied a weak "nudging" towards actual meteorology by the assimilation of analysis data from the European Centre for Medium-range Weather Forecasting (ECMWF) through the Newtonian relaxation of four prognostic model variables: temperature, divergence, vorticity and the logarithm of surface pressure (van Aalst et al., 2004). The first 5 months of the simulation are regarded as spin up period and these results are not considered in our analysis.

Output has been archived as 1-hourly instantaneous fields to capture an hourly resolved diurnal cycle. In the sensitivity runs $\mathrm{S} 1, \mathrm{~S} 2$ and $\mathrm{S} 3$, HONO levels were parameterized such that the $\mathrm{HONO} / \mathrm{NO}_{\mathrm{x}}$ ratio is fixed at $0.01,0.02$ and 0.04 , respectively (see Sect. 3.3). This was achieved by an iterative correction of $\mathrm{HONO}$ and $\mathrm{NO}_{\mathrm{x}}$ (i.e., without disturbing the reactive nitrogen budget), which was applied every minute, thus limiting deviations in the $\mathrm{HONO} / \mathrm{NO}_{\mathrm{x}}$ ratio to within \pm 0.005 .

\subsection{Field measurements}

Average diurnally resolved data sets from eight different field measurement campaigns (see Table 1) were used to analyse the day- and nighttime HONO chemistry. HOxComp took place at the Jülich Research Centre, Germany during 9-11 July 2005 (we used only the diurnal profile of the cloud free day, 10 July, Elshorbany et al., 2012); the Santiago de Chile campaigns took place during 8-20 March 2005 (Santiago_S, Elshorbany et al., 2009a) and during 25 May to 7 June 2005 (Santiago_W, diurnal average of cloud free days only, Elshorbany et al., 2010a); the PMTACS-NY campaign took place from 10 July to 2 August 2001 in New York (New York, Ren et al., 2003); the Mexico City Metropolitan Area campaign took place during 14-31 March 2006 (MCMA-2006, Dusanter et al., 2009); the DOMINO campaign took place in southwestern Spain during NovemberDecember, 2008 (DOMINO, diurnal average of cloud free days only, Sörgel et al., 2011a) and we used two gradient measurement data sets obtained during a field measurement 


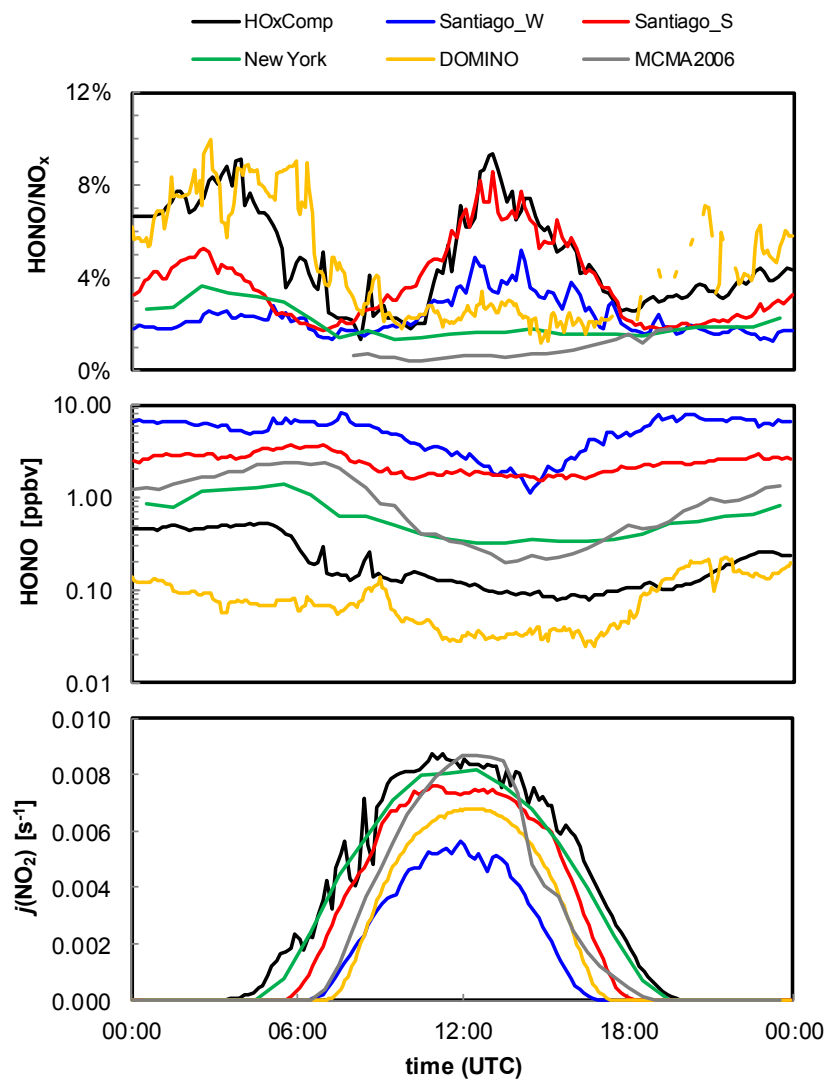

Fig. 1. Diurnal cycles of the $\mathrm{HONO} / \mathrm{NO}_{\mathrm{x}}$ ratio, $\mathrm{HONO}$ and $j\left(\mathrm{NO}_{2}\right)$ observed in different field measurement campaigns. For abbreviations and references, see the text.

campaign at a $55 \mathrm{~m}$ tall building in Santiago de Chile from 17-29 November 2009 at the altitudes of $6 \mathrm{~m}$ (3rd floor, Santiago_3) and $53 \mathrm{~m}$ (21st floor, Santiago_21) above the ground (Villena et al., 2011a). In addition, measured average concentrations of $\mathrm{HONO}$ and $\mathrm{NO}_{\mathrm{x}}$ from 7 other field measurement campaigns, adopted from $\mathrm{Li}$ et al. (2012), were also investigated (see Table 1). These measurement campaigns were performed in three different continents (from $52^{\circ} \mathrm{N}$ to $33^{\circ} \mathrm{S}$ and from $116^{\circ} \mathrm{E}$ to $99^{\circ} \mathrm{W}$ ) under a range of meteorological conditions. These measurements also encompass a wide range of different $\mathrm{NO}_{\mathrm{x}}$ conditions, typically from $\mathrm{NO}$ sensitive conditions (e.g., HOxComp) to VOC sensitive conditions (e.g., Santiago and New York). Furthermore, the results obtained from the analysis of these data are compared with other field campaigns reported in the literature. The range of HONO mixing ratios obtained from these data sets represents the minimum and maximum HONO levels measured during the last decade and therefore, represent an optimal global overview of HONO measurements.

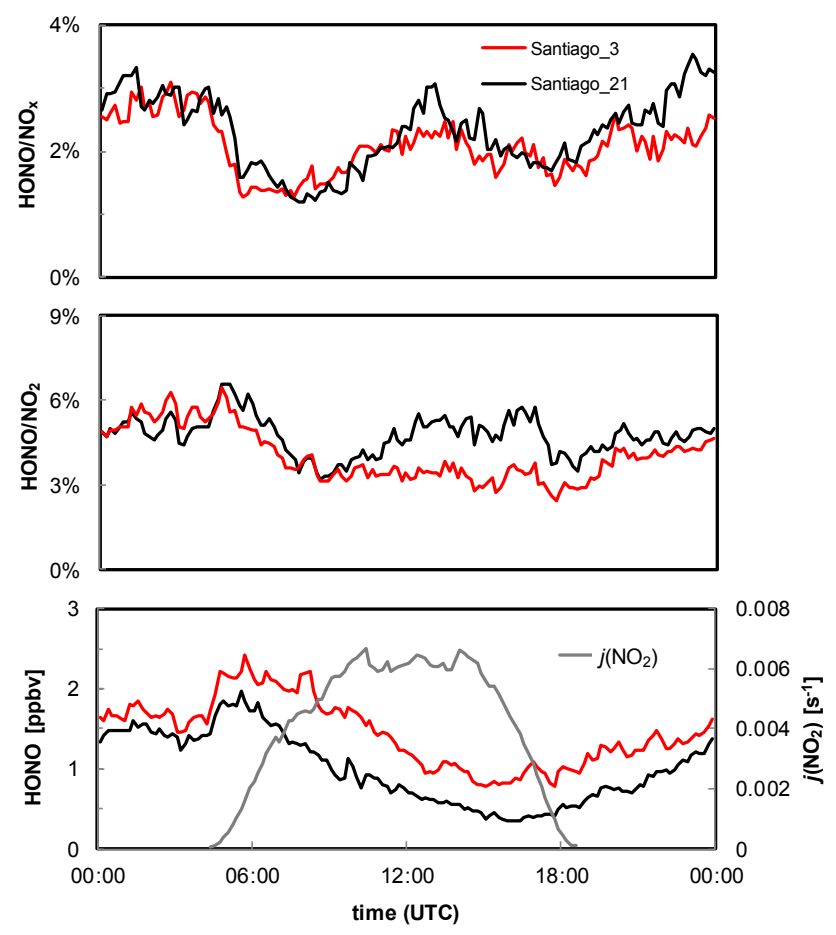

Fig. 2. Average diurnal cycles of $\mathrm{HONO}$ and $\mathrm{NO}_{\mathrm{x}}$ measurements at 6 (Santiago_3) and 53 (Santiago_21) meters altitude in Santiago de Chile, 2009, adopted from Villena et al. (2011a).

\subsection{Intercomparison of field measurements}

The average measured diurnal profiles of $\mathrm{HONO} / \mathrm{NO}_{\mathrm{x}}$, $\mathrm{HONO}$ and $j\left(\mathrm{NO}_{2}\right)$ for the first 8 data sets in Table 1 are shown in Figs. 1 and 2. The HONO diurnal profiles typically show increasing mixing ratios after sunset due to HONO formation by heterogeneous reactions, direct emissions and the absence of photolytic loss processes, in addition to the decrease in boundary layer height (i.e. the mixing volume). Owing to its short lifetime of about $10-30 \mathrm{~min}$ and the increased vertical mixing, HONO decreases after sunrise, reaching its minimum levels during the afternoon. Influenced by relatively high nighttime values, $24 \mathrm{~h}$ average HONO levels range from about 0.1 to $5 \mathrm{ppbv}$ (see Table 1). Average daytime HONO mixing ratio range from about $0.03 \mathrm{ppbv}$ during the DOMINO campaign in southern Spain (autumn) to about $3.25 \mathrm{ppbv}$ in Santiago de Chile (winter). Daytime $\mathrm{HONO} / \mathrm{NO}_{\mathrm{x}}$ ratios range from about 0.01 during the MCMA-2006 to about 0.05 during the Santiago_S with average and median values of about 0.02 for all campaigns. The very low values of the $\mathrm{HONO} / \mathrm{NO}_{\mathrm{x}}$ ratio during MCMA-2006 in comparison to the other campaigns is partly due to the different spatial measurement of HONO by LP-DOAS (Long-Path Differential Optical Absorption Spectroscopy) and $\mathrm{NO}_{\mathrm{x}}$ by a local standard instrument (see also Sect. 3.2.2). 
It is worth mentioning that measured $\mathrm{HONO} / \mathrm{NO}_{\mathrm{x}}$ ratios, using the LOPAP technique at polar and high altitude mountain sites were also within the above-mentioned range though at lower measured $\mathrm{HONO}$ and $\mathrm{NO}_{\mathrm{x}}$ mixing ratios. For example, diurnal average $\mathrm{HONO} / \mathrm{NO}_{\mathrm{x}}$ ratios of 0.046 and 0.025 were reported at high altitude mountain sites at Jungfraujoch and Zugspitze, respectively (Kleffmann and Wiesen et al., 2008). Similarly, the diurnal average measured $\mathrm{HONO} / \mathrm{NO}_{\mathrm{x}}$ ratio at a polar site in Barrow, Alaska was $0.062 \pm 0.048$ (Villena et al., 2011b).

Average diurnal profiles of gradient HONO measurements in Santiago de Chile at 6 and $53 \mathrm{~m}$ altitude are presented in Fig. 2. The diurnal profiles show a clear vertical gradient with HONO mixing ratios at $53 \mathrm{~m}$ of about $60 \%$ of those at $6 \mathrm{~m}$ during daytime. Similar HONO gradient were observed previously in the Mexico City metropolitan area during the MCMA-2003 at 70 and $16 \mathrm{~m}$ altitude (Volkamer et al., 2010). Both $\mathrm{NO}$ and $\mathrm{NO}_{2}$ show similar gradients while $\mathrm{O}_{3}$ increases with height owing to the inter-conversion of $\mathrm{NO} / \mathrm{NO}_{2}$ through reactions of $\mathrm{NO}$ (emitted at ground level) with $\mathrm{RO}_{2}$ and $\mathrm{HO}_{2}$ (Villena et al., 2011a). Due to the stronger absolute gradient of $\mathrm{NO}_{2}, \mathrm{HONO} / \mathrm{NO}_{2}$ ratios show an opposite strong gradient during daytime while $\mathrm{HONO} / \mathrm{NO}_{\mathrm{x}}$ ratios appear to be almost unaffected. Similarly, Kleffmann (2007) also showed that the HONO/NO ratio decreases only little with altitude from about $2.5 \%$ at $10 \mathrm{~m}$ to about $2 \%$ at $190 \mathrm{~m}$. The photolysis of HONO releasing $\mathrm{OH}$ and $\mathrm{NO}$, enhances photochemical oxidation processes, which subsequently catalytically convert $\mathrm{NO}$ into $\mathrm{NO}_{2}$ which in turn photolyses to form $\mathrm{O}_{3}$. Consequently, the relative change of $\mathrm{HONO}$ as a result of its photolysis is also reflected in the $\mathrm{O}_{3}$ and $\mathrm{NO}_{x}$ levels resulting in a nearly constant $\mathrm{HONO} / \mathrm{NO}_{\mathrm{x}}$ ratio. Therefore, the HONO/NO${ }_{2}$ ratio may be considered a good measure of HONO during the night (see also Sörgel et al., 2011b) while during daytime the HONO/NO ratio seems to be more suited (see Sect. 3.3).

\section{Results and discussion}

\subsection{Average $\mathrm{HONO} / \mathrm{NO}_{\mathrm{x}}$ ratio}

To obtain an overview of measured $\mathrm{HONO} / \mathrm{NO}_{\mathrm{x}}$ ratios, daytime and $24 \mathrm{~h}$ average mixing ratios of $\mathrm{HONO}$ and $\mathrm{NO}_{\mathrm{x}}$, based on all available data sets, are plotted in Fig. 3. A high correlation $\left(R^{2}=0.87\right)$ is obtained between HONO and $\mathrm{NO}_{\mathrm{x}}$ during daytime with a linear regression slope of $0.02 \pm 0.002$ (Fig. 3, upper panel). Similarly, a high correlation $\left(R^{2}=0.90\right)$ is obtained for the $24 \mathrm{~h}$ average values with a linear regression slope of $0.02 \pm 0.001$. However, for the DOMINO, BERLIOZ, HOxCOMP, PRIDE-PRD2006 (Back Garden), Yufa and Kathmandu campaigns a slightly different regression slope of $0.05( \pm 0.004)$ was found (Fig. 3, lower panel). This is likely due to the relatively high $\mathrm{NO}_{2} / \mathrm{NO}_{\mathrm{x}}$ ratio during these campaigns (see Table 1), especially dur-

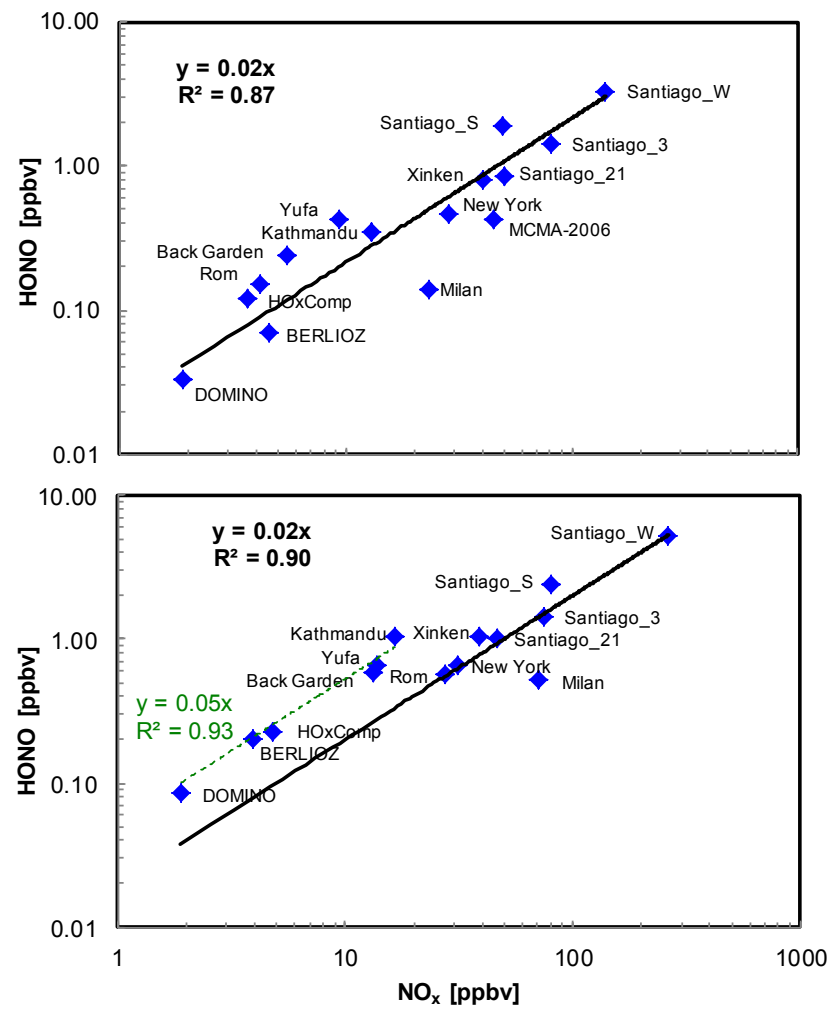

Fig. 3. Correlation between daytime (upper panel) and $24 \mathrm{~h}$ (lower panel) average $\mathrm{HONO}$ and $\mathrm{NO}_{\mathrm{x}}$ mixing ratios observed in different field measurement campaigns. For details and references, see Table 1 and the text.

ing the night when the influence of direct $\mathrm{NO}$ emissions in these regions is small. These measurement campaigns were characterised by a high NO morning peak, decreasing to less than $1 \mathrm{ppbv}$ during the rest of the day due to a change in wind direction as mentioned in the respective references (Sörgel et al., 2011a; Alicke et al., 2003; Elshorbany et al., 2012; Li et al, 2012; Yu et al., 2009, respectively, except for the Yufa campaign, for which the data were obtained from $\mathrm{Li}$ et al., 2012). The higher $\mathrm{NO}_{2}$ fraction during the night leads to higher HONO via its heterogeneous formation in the dark, resulting in higher $\mathrm{HONO} / \mathrm{NO}_{\mathrm{x}}$ ratios compared to other measurement campaigns. This influence is less pronounced during daytime as the $\mathrm{NO}_{2} / \mathrm{NO}_{\mathrm{x}}$ ratios for all campaigns are much closer (see Table 1). Since HONO photolysis only influences $\mathrm{HO}_{\mathrm{x}}, \mathrm{O}_{3}$ and other oxidants during daytime, the $\mathrm{HONO} / \mathrm{NO}_{\mathrm{x}}$ regression slope of $0.02 \pm 0.001$ determined above appears to be representative and may be used to investigate the impact on $\mathrm{HO}_{\mathrm{x}}$ and oxidant chemistry. Detailed analyses of the factors controlling the HONO diurnal profile as a function of $\mathrm{NO}_{\mathrm{x}}$ are presented in the next section. 


\subsection{HONO diurnal profile}

To determine the factors controlling the HONO mixing ratio as a function of $\mathrm{NO}_{\mathrm{x}}$, the aforementioned 8 field measurement data sets (HOxComp, Santiago_S, Santiago_W, Santiago_3, Santiago_21, DOMINO, MCMA-2006 and New York) have been investigated. During the first 6 measurement campaigns, HONO was measured by the sensitive LOPAP (Long Path Absorption Photometer) technique (Heland et al., 2001; Kleffmann et al., 2002), which showed excellent agreement with the (absolute) DOAS measurements, both in smog chamber and in urban atmospheric conditions. The good performance of the LOPAP instrument is related to the efficient correction of chemical interferences (Kleffmann et al., 2006). During MCMA-2006, HONO was measured using LP-DOAS (Dusanter et al., 2009 and references therein), which selectively detects HONO based on it specific UV absorption, thus free of sampling artefacts and chemical interferences (Platt and Perner, 1980). During the New York campaign (Ren et al., 2003) HONO was measured by aqueousphase scrubbing and high performance liquid chromatography (HPLC) analysis (Huang et al., 2002), which has been used (also in a modified form) in several field measurement campaigns (e.g., Zhou et al., 2002; Ren et al., 2010; Zhang et al., 2012). It is worth mentioning that HONO measurements under very clean conditions, using wet-chemical techniques (other than LOPAP) have been reported to be biased by uncorrected interferences leading to artificially high $\mathrm{HONO} / \mathrm{NO}_{\mathrm{x}}$ ratios (Kleffmann et al., 2006; Kleffmann and Wiesen, 2008; Su et al., 2008; Lu et al., 2010; Villena et al., 2011b; Zhang et al., 2012). Recent studies acknowledged this problem and corrected for these interferences (e.g., Su et al., 2008) or modified the technique to minimize them (e.g., Ren et al., 2010; Zhang et al., 2012). Under high $\mathrm{NO}_{\mathrm{x}}$ polluted conditions this problem is less pronounced (e.g., Kleffmann et al., 2006; Kleffmann and Wiesen, 2008). In the current study, only HONO measurements by LOPAP are considered for low $\mathrm{NO}_{\mathrm{x}}$ conditions while for high $\mathrm{NO}_{\mathrm{x}}$ conditions, LOPAP, DOAS and aqueous-phase scrubbing and HPLC or ion chromatography (IC) analysis techniques are used. To analyse the factors influencing the HONO diurnal profile, we distinguish 4 time sectors, midnight to sunrise (sector A), sunrise to mid-noon (sector B), mid-noon to sunset (sector C) and from sunset to midnight (sector D), grouped into two main sectors, nighttime (A and D) and daytime (B and C). The onset of sunrise and sunset is defined at $30 \%$ of the maximum measured $j\left(\mathrm{NO}_{2}\right)$ values. The duration of each sector period varies based on the $j\left(\mathrm{NO}_{2}\right)$ values measured in each study. The obtained linear regression expression is then used to calculate HONO mixing ratios in each sector in terms of $\mathrm{NO}_{\mathrm{x}}$ and the other related parameters.

\subsubsection{Nighttime HONO levels}

In contrast to daytime HONO levels, which are generally higher than expected based on model calculations (e.g., Kleffmann et al., 2005; Acker et al., 2006; Li et al. (2010); Sörgel et al., 2011a; Su et al., 2011; Elshorbany et al., 2012), HONO concentrations during nighttime can be largely explained by known sources, i.e., the heterogeneous reaction on humid surfaces (Alicke et al., 2002) and direct emissions (Vogel et al., 2003). All measurement campaigns are included in this analysis except MCMA-2006, for which no nighttime HONO data are available. Though the correlation between $\mathrm{HONO}$ and $\mathrm{NO}_{\mathrm{x}}$ during both night sectors, A and D, reveal a similar slope of about 0.02 (see Fig. 4), the $\mathrm{HONO} / \mathrm{NO}_{\mathrm{x}}$ ratio itself is found to be logarithmically related to $\mathrm{NO}_{\mathrm{x}}$, which can be explained by the nighttime heterogeneous formation of HONO (Kleffmann et al., 2003). This is confirmed by the HONO/NO dependency on wind speed (ws) (see Fig. 4). Similarly, Elshorbany et al. (2009a) showed that the HONO heterogeneous rate constant in the dark (calculated using the $\mathrm{HONO} / \mathrm{NO}_{2}$ ratio) correlates inversely with the wind speed. The positive correlation between $\mathrm{HONO} / \mathrm{NO}_{\mathrm{x}}$ and the wind speed in Fig. 4 is related to the anti-correlation typically observed between HONO and the $\mathrm{NO}_{2} / \mathrm{NO}_{\mathrm{x}}$ ratio for all investigated campaigns (see Table 1 ). In addition, the slope of the $\mathrm{HONO} / \mathrm{NO}_{\mathrm{x}}$ ratio versus $\mathrm{NO}_{\mathrm{x}}$ was found to be about two times higher in sector A compared to sector D (see Fig. 4), resulting in the following two regression equations:

$[\mathrm{HONO}] \mathrm{A}=$

$\left((-0.011 \pm 0.002) \ln \left(\left[\mathrm{NO}_{\mathrm{x}}\right]\right)+(0.078 \pm 0.009)\right) \times\left[\mathrm{NO}_{\mathrm{x}}\right]$

$[\mathrm{HONO}] \mathrm{D}=$

$\left((-0.005 \pm 0.001) \ln \left(\left[\mathrm{NO}_{\mathrm{x}}\right]\right)+(0.043 \pm 0.004)\right) \times\left[\mathrm{NO}_{\mathrm{x}}\right]$

Similarly, an anti-correlation between $\mathrm{HONO} / \mathrm{NO}_{\mathrm{x}}$ ratio and $\mathrm{NO}_{\mathrm{x}}$ was previously reported (Sörgel et al., 2011b). Again, for the correlation between $\mathrm{HONO} / \mathrm{NO}_{\mathrm{x}}$ ratio and ws, the slope in sector $\mathrm{A}$ is higher than that in sector $\mathrm{D}$, though with a higher correlation coefficient in sector D (see Fig. 4). Nevertheless, as shown in Fig. 5, simulated HONO using equations (Eq. 1) and (Eq. 2) (sector A and D, respectively) is only improved for measurement campaigns with a nighttime HONO/NO $\mathrm{Na}_{\mathrm{x}}$ ratio $>0.02$, i.e., HOxComp, Santiago_S and DOMINO, compared to that using the mean $\mathrm{HONO} / \mathrm{NO}_{\mathrm{x}}$ ratio of 0.02 , while for other campaigns measured $\mathrm{HONO}$ was reasonably well simulated based on the mean $\mathrm{HONO} / \mathrm{NO}_{\mathrm{x}}$ ratio of 0.02 .

\subsubsection{Daytime HONO mixing ratio}

During daytime, a similar regression slope of $0.02 \pm 0.002$ between measured $\mathrm{HONO}$ and $\mathrm{NO}_{\mathrm{x}}$ mixing ratio was obtained for all measurement campaigns (see Fig. 6), though with a lower correlation coefficient in comparison to 

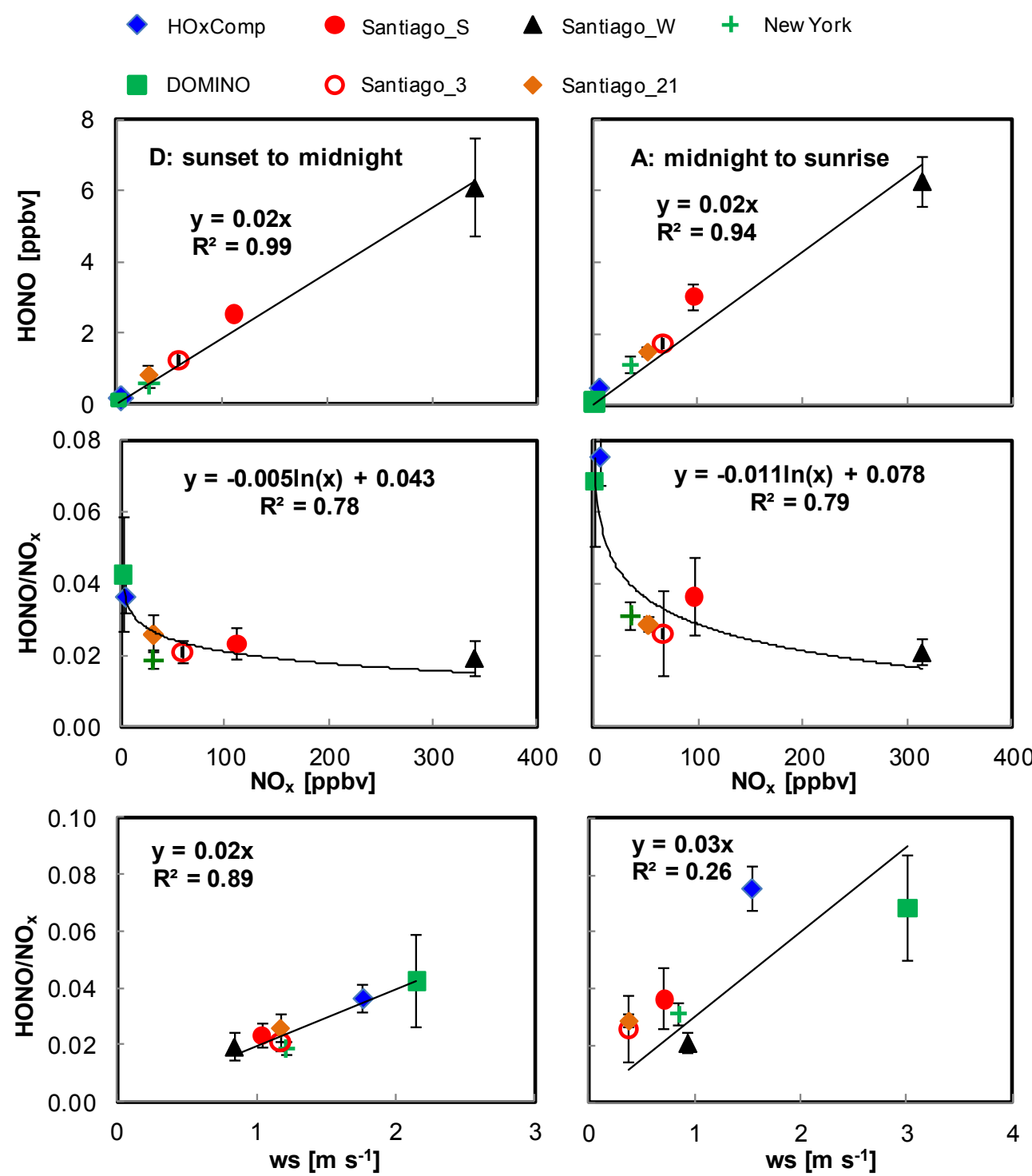

Fig. 4. Correlation of nighttime average $\mathrm{HONO}$ and $\mathrm{NO}_{\mathrm{x}}$ mixing ratios as well as wind speed (ws) for sector A (right panel, from midnight to sunrise) and sector D (left panel, from sunset to midnight). Error bars represent $1 \sigma$ of the mean.

nighttime values, which is mainly due to the low correlation between $\mathrm{HONO}$ and $\mathrm{NO}_{\mathrm{x}}$ during the afternoon (sector $\mathrm{C}$, see below). However, in contrast to nighttime conditions, the $\mathrm{HONO} / \mathrm{NO}_{\mathrm{x}}$ ratio during daytime is independent of $\mathrm{HONO}$ and $\mathrm{NO}_{\mathrm{x}}$ mixing ratios while it has a light dependency (given by $j\left(\mathrm{NO}_{2}\right)$, though with a low correlation coefficient $\left(R^{2}=0.23\right)$. These results are in agreement with Zhang et al. (2012), who showed that the daytime HONO flux does not correlate significantly with measured $\mathrm{NO}_{\mathrm{x}}$ mixing ratios, suggesting that under these conditions $\mathrm{NO}_{\mathrm{x}}$ is not an important precursor of HONO daytime formation. In addition, using the Community Multiscale Air Quality (CMAQ) model, Czader et al. (2012) demonstrated that photochemical HONO formation can be a strong source during daytime, which directly impacts $\mathrm{HO}_{\mathrm{x}}$ and ozone levels.
During daytime, HONO mixing ratios are controlled by the photostationary state concentration of HONO, [HONO]pss, calculated from the known gas phase chemistry by the following equation:

$[\mathrm{HONO}] \mathrm{pss}=\frac{k_{\mathrm{OH}+\mathrm{NO}}[\mathrm{OH}][\mathrm{NO}]}{j(\mathrm{HONO})+k_{\mathrm{OH}+\mathrm{HONO}}[\mathrm{OH}]}$,

in addition to other sources that are not known or not accounted for, henceforth denoted as "unidentified". Owing to their negligible contributions during daytime, heterogeneous formation of HONO and its deposition on the ground (e.g., Elshorbany et al, 2009; Sörgel et al., 2011a) are ignored. Given the reported low $\mathrm{HONO} / \mathrm{NO}_{\mathrm{x}}$ ratio of $0.3-0.8 \%$ for directly emitted HONO estimated at a $\mathrm{NO} / \mathrm{NO}_{\mathrm{x}}$ ratio of $>0.9$ (Kurtenbach et al., 2001), and considering the variable low 

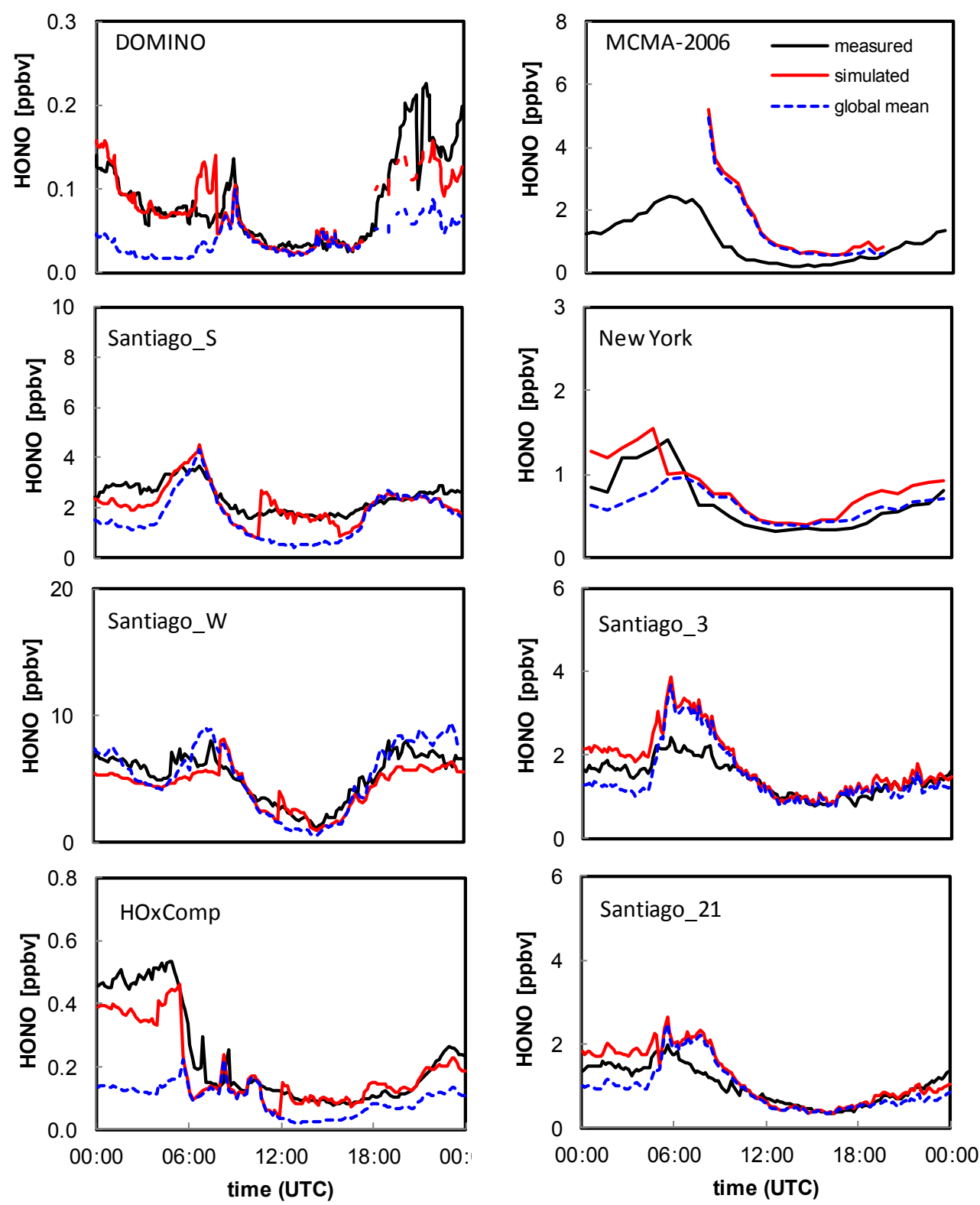

Fig. 5. Simulated diurnal HONO cycles based on the Eq. (1) to Eq. (6) for the different sectors (simulated) and those based on the mean $\mathrm{HONO} / \mathrm{NO}_{\mathrm{x}}$ ratio of 0.02 (global mean), compared to measurements in different campaigns. Small spikes appear between sectors due to the different parameterizations applied.

$\mathrm{NO} / \mathrm{NO}_{\mathrm{x}}$ ratios (0.2 to 0.6$)$ and the much higher measured $\mathrm{HONO} / \mathrm{NO}_{\mathrm{x}}$ ratios for the investigated campaigns, emitted HONO contributions are not expected to contribute significantly to measured HONO levels (Su et al., 2008) during the investigated campaigns and are therefore not considered in the following calculation. For the estimation of [HONO]pss the $\mathrm{OH}$ concentration and the HONO photolysis frequency $(j(\mathrm{HONO}))$ in addition to measurements of $\mathrm{NO}$ and HONO mixing ratios are required, which were available only for four measurement campaigns, HOxComp, Santiago_S, Santiago_W and DOMINO. For all campaigns [HONO]pss was calculated using the IUPAC recommendations (Atkinson et al., 2004). During daytime [HONO]pss constituted 29, 72, 55 and $50 \%$ of measured HONO levels during HOxComp, Santiago_S, Santiago_W and DOMINO, respectively. Unidentified HONO mixing ratios were calculated by subtracting the calculated [HONO]pss from the measured HONO mixing ratios. The largest contributions of [HONO]pss typically occur during the early morning (sector $\mathrm{B}$, from sunrise to midnoon) reaching a maximum during the rush hour.

As shown in Fig. 7, high correlations are obtained between average HONO, [HONO]pss and unidentified HONO 

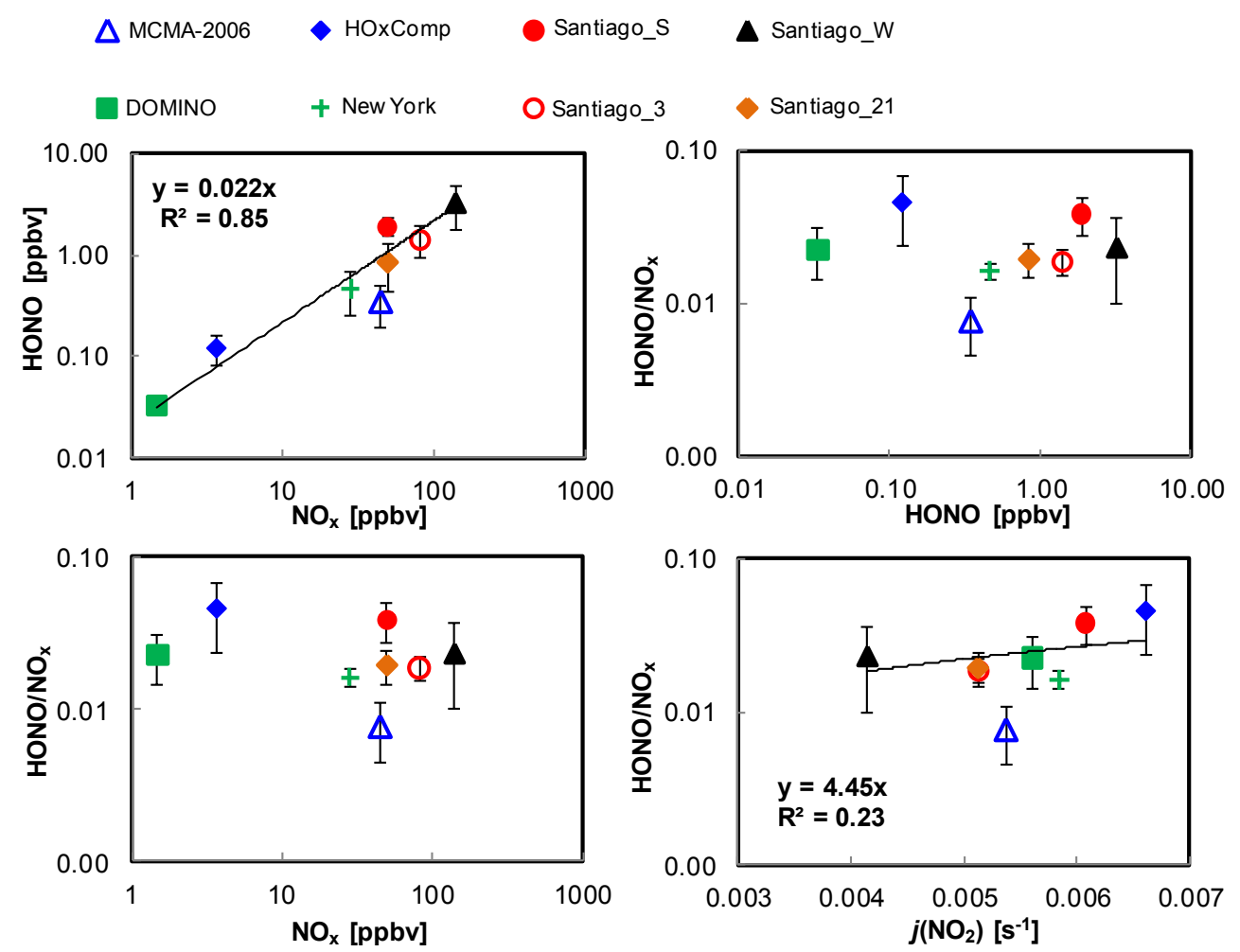

Fig. 6. Correlations between $\mathrm{HONO}, \mathrm{NO}_{\mathrm{x}}$ and $j\left(\mathrm{NO}_{2}\right)$ daytime average values for different measurement campaigns. Error bars represent 1 $\sigma$ of the mean.

mixing ratios versus $\mathrm{NO}_{\mathrm{x}}$ levels for the investigated measurement campaigns during both, sector $\mathrm{B}$ and daytime (sectors $\mathrm{B}+\mathrm{C}$ ). However, the regression slopes for the measured $\mathrm{HONO}$ and unidentified $\mathrm{HONO}$ levels versus $\mathrm{NO}_{\mathrm{x}}$ are higher during daytime in comparison to that of sector $\mathrm{B}$, showing that unidentified sources contribute most during the afternoon, again in good agreement with previous studies, which showed that the high afternoon $\mathrm{HONO} / \mathrm{NO}_{\mathrm{x}}$ ratio points towards unknown HONO daytime sources (e.g., Kleffmann et al, 2005; Elshorbany et al., 2009a, 2010b, 2012). Consequently, a higher correlation coefficient is obtained for the relationship between $\mathrm{HONO}$, $[\mathrm{HONO}]$ pss and $\mathrm{NO}_{\mathrm{x}}$ during sector $\mathrm{B}$ in comparison to the average daytime values. In contrast, for [HONO]pss, similar slopes are obtained during daytime as well as sector B, implying similar average contributions (i.e., of [HONO]pss to HONO measured mixing ratios) during both sectors, B and C. For sector B, the following linear regression expressions are derived:

$$
\begin{aligned}
{[\mathrm{HONO}] \mathrm{pss} } & =(0.014 \pm 0.001) \times\left[\mathrm{NO}_{\mathrm{x}}\right] \\
{[\mathrm{HONO}] \mathrm{B} } & =(0.021 \pm 0.001) \times\left[\mathrm{NO}_{\mathrm{x}}\right]
\end{aligned}
$$

As shown in Fig. 5, HONO mixing ratios in sector B calculated by equation (Eq. 5) and by the global mean of 0.02 are similar and in very good agreement with measurements, related to the similar slope of $\mathrm{HONO} / \mathrm{NO}_{\mathrm{x}}$ in sector $\mathrm{B}$ and the mean $\mathrm{HONO} / \mathrm{NO}_{\mathrm{x}}$ ratio of 0.02 , except for Santiago_3, San- tiago_21 and MCMA-2006. In fact, measured HONO during sector B for Santiago_3 and Santiago_21 could have been accurately simulated based on (Eq. 4) alone, which shows that measured HONO during sector B in these data sets can be largely explained by [HONO]pss. However, for consistency we used (Eq. 5) for sector B in all data sets. For MCMA2006, the overestimation of HONO mixing ratios in sector B is due to the very high measured $\mathrm{NO}_{\mathrm{x}}$ mixing ratio, which is not related to that of HONO (see below).

The noon to sunset time period (sector $\mathrm{C}$ ) is the most important one in the HONO diurnal profile, during which unidentified daytime HONO sources contribute most significantly. The linear regression analysis for this time period was found to result in two different slopes as shown in Fig. 8 (middle panel). For measurement campaigns with a $\mathrm{HONO} / \mathrm{NO}_{\mathrm{x}}$ ratio of $\leq 0.02$, i.e., DOMINO, Santiago_3, Santiago_21, New York and MCMA-2006, a high correlation is obtained with a regression slope of $0.017 \pm 0.003$, while measurement campaigns with a $\mathrm{HONO} / \mathrm{NO}_{\mathrm{x}}$ ratio $>0.02$, i.e., HOxComp, Santiago_S, Santiago_W indicate a regression slope of $0.042 \pm 0.01$ (Fig. 8, middle panel). The regression slope for measurement campaigns with $\mathrm{HONO} / \mathrm{NO}_{\mathrm{x}}$ ratios $\leq 0.02$ is quite comparable to that of [HONO]pss $v s \mathrm{NO}_{\mathrm{x}}$ (see Fig. 7), which shows that HONO mixing ratios during this time period for these measurement campaigns can be described accurately by [HONO]pss, with an additional 


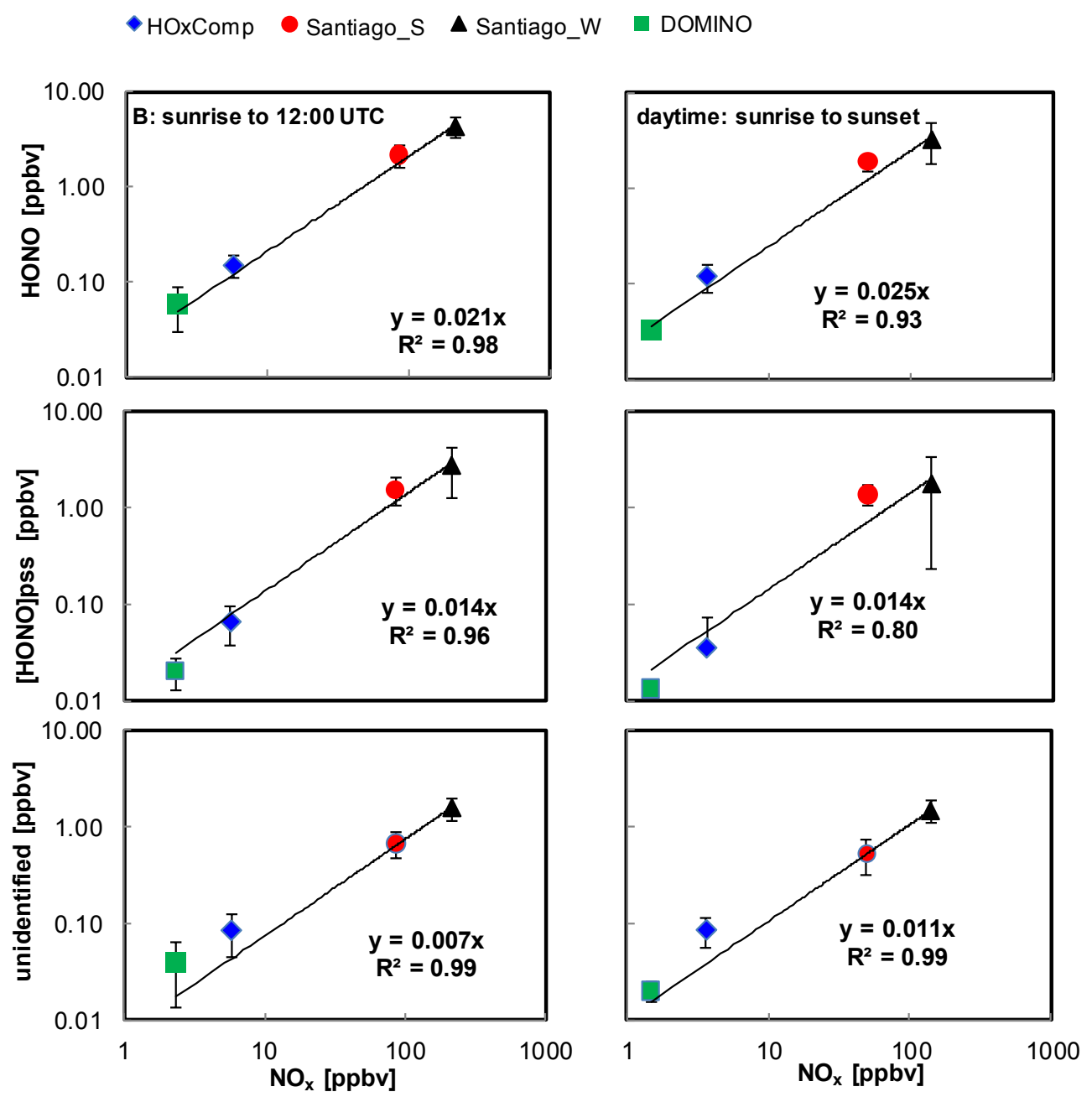

Fig. 7. Correlation between $\mathrm{HONO}$, [HONO]pss, unidentified $\mathrm{HONO}$ and $\mathrm{NO}_{\mathrm{x}}$ during sector $\mathrm{B}$ (left, sunrise to 12:00 UTC) and during daytime (right, sunrise to sunset). Error bars represent $1 \sigma$ of the mean.

small contribution from unidentified sources. Interestingly, a very high correlation $\left(R^{2}=0.99\right)$ between the $\mathrm{HONO} / \mathrm{NO}_{\mathrm{x}}$ ratio and $j\left(\mathrm{NO}_{2}\right)$ has been obtained only for measurement campaigns with $\mathrm{HONO} / \mathrm{NO}_{\mathrm{x}}$ ratios $>0.02$ (see Fig. 8), from which $\mathrm{HONO}$ mixing ratios during sector $\mathrm{C}$ can be calculated as:

$[\mathrm{HONO}] \mathrm{C}=(9.42 \pm 0.16) j\left(\mathrm{NO}_{2}\right) \times\left[\mathrm{NO}_{\mathrm{x}}\right]$

For those with a $\mathrm{HONO} / \mathrm{NO}_{\mathrm{x}}$ ratio $\leq 0.02$, a much worse correlation $\left(R^{2}=0.44\right)$, even with a negative slope was obtained. Consequently, for measurement campaigns with $\mathrm{HONO} / \mathrm{NO}_{\mathrm{x}}$ ratios $>0.02$, calculated HONO mixing ratios based on the above equation (Eq. 6) match the measurements well (see Fig. 5), while for those with a $\mathrm{HONO} / \mathrm{NO}_{\mathrm{x}}$ ratio $\leq 0.02$, measured HONO mixing ratios are better simulated using the average of 0.02 . One potential explanation for this different $j\left(\mathrm{NO}_{2}\right)$ dependency is that for measurement campaigns with a $\mathrm{HONO} / \mathrm{NO}_{\mathrm{x}}$ ratio $\leq 0.02$, unknown daytime HONO sources that are $j\left(\mathrm{NO}_{2}\right)$ dependent do not con- tribute significantly to the measured HONO mixing ratios. Indeed, for two of these measurement campaigns, DOMINO and New York, unidentified daytime HONO source strengths of about 100 and $150 \mathrm{pptv} \mathrm{h}^{-1}$, respectively were reported, being very low compared to that of about $0.33,1.7$ and $2.5 \mathrm{ppbv} \mathrm{h}^{-1}$ for HOxComp, Santiago_S and Santiago_W, respectively. Similarly, the unknown source strengths for other campaigns reported in the literature are also in the range of 200-500 pptv h ${ }^{-1}, 500 \mathrm{pptv} \mathrm{h}^{-1}$ and up to $2 \mathrm{ppbvh}^{-1} \mathrm{cal}^{-}$ culated for rural, semi-urban and urban conditions, respectively (Kleffmann et al., 2007). For MCMA-2006, an additional daytime HONO source was reported (Dusanter et al., 2009) despite the low average daytime $\mathrm{HONO} / \mathrm{NO}_{\mathrm{x}}$ ratio of about 0.01 . However, as mentioned above (Sect. 2.2), this is due to the different spatial account of $\mathrm{HONO}$ and $\mathrm{NO}_{\mathrm{x}}$ (i.e., measuring different air masses of $\mathrm{HONO}$ and $\mathrm{NO}_{x}$ ). During MCMA-2006 HONO was measured using an LP-DOAS system over an optical path length of $5285 \mathrm{~m}$ while $\mathrm{NO}_{\mathrm{x}}$ was measured using a local commercial standard instrument, 

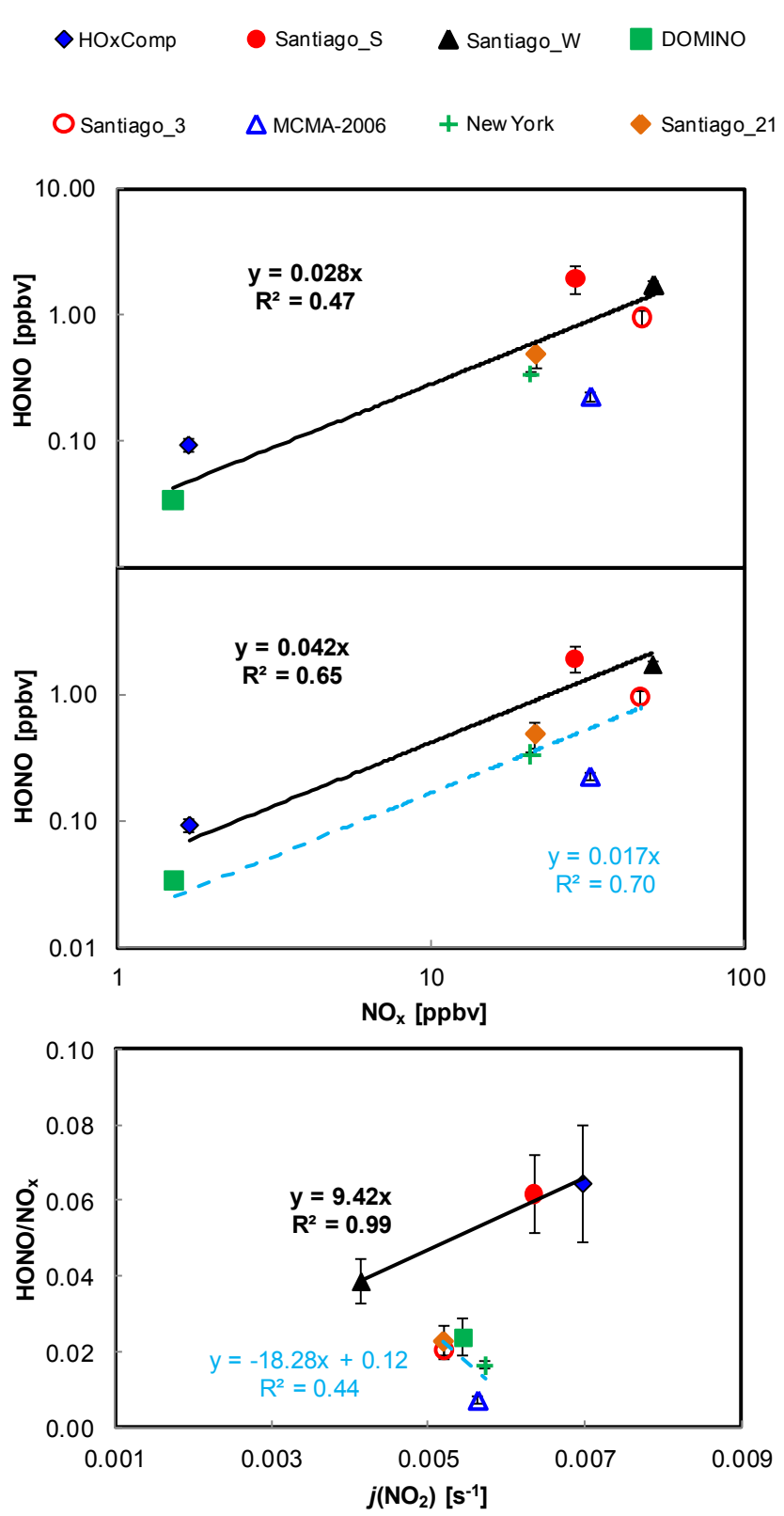

Fig. 8. Correlations between average afternoon (sector $\mathrm{C}$, mid-noon to sunset) HONO mixing ratios versus the corresponding $\mathrm{NO}_{\mathrm{x}}$ and $j\left(\mathrm{NO}_{2}\right)$ values observed in different measurement campaigns. Error bars represent $1 \sigma$ of the mean.

which is known to be affected by interferences from other $\mathrm{NO}_{y}$ components (e.g., $\mathrm{HNO}_{3}, \mathrm{PAN}, \mathrm{RNO}_{3}$, etc). Therefore, the low $\mathrm{HONO} / \mathrm{NO}_{\mathrm{x}}$ ratio of 0.01 is likely to be caused by higher measured $\mathrm{NO}_{\mathrm{x}}$ levels in different air masses. Unfortunately, no strict method or correlation could be found to predict the $\mathrm{HONO} / \mathrm{NO}_{\mathrm{x}}$ ratio (i.e., $>0.02$ or $\leq 0.02$ ). Therefore the different dependency of $\mathrm{HONO} / \mathrm{NO}_{\mathrm{x}}$ on $j\left(\mathrm{NO}_{2}\right)$ can only be used as an indicator of the presence of significant unknown HONO sources, rather than to predict the HONO concentration.

\subsubsection{Unidentified HONO sources}

The contribution of unidentified HONO sources to measured $\mathrm{HONO}$ during the afternoon (sector $\mathrm{C}$, from noon to sunset) was largest during HOxComp $(\sim 91 \%)$ followed by Santiago_W $(\sim 69 \%)$ and Santiago_S $(\sim 25 \%)$. As shown in Fig. 9, high correlations are obtained between unidentified HONO mixing ratios and their derived source strength $\left(\mathrm{ppbh}^{-1}\right)$ with $j\left(\mathrm{NO}_{2}\right), j\left(\mathrm{O}^{1} \mathrm{D}\right)$ and temperature for sector $\mathrm{C}$. The good agreement for both $j\left(\mathrm{NO}_{2}\right)$ and $j\left(\mathrm{O}^{1} \mathrm{D}\right)$ relates to the onsets of sunrise and sunset being defined at $30 \%$ of the maximum $j\left(\mathrm{NO}_{2}\right)$ values, when the $j\left(\mathrm{O}^{1} \mathrm{D}\right)$ values correspond to about $10 \%$ of their daytime maximum. This method allows investigating the dependency of unidentified daytime $\mathrm{HONO}$ sources on both, $j\left(\mathrm{NO}_{2}\right)$ and $j\left(\mathrm{O}^{1} \mathrm{D}\right)$. In previous studies (e.g., Elshorbany et al., 2009a, 2012), better agreement was obtained for the correlation between unidentified HONO sources and $j\left(\mathrm{NO}_{2}\right)$ in comparison to $j\left(\mathrm{O}^{1} \mathrm{D}\right)$ by considering the full photolysis frequency range of these photolysis rates, and the latter produces an intercept due to the smaller span of $j\left(\mathrm{O}^{1} \mathrm{D}\right)$. However, the good correlation between unidentified HONO sources (see Fig. 9) and temperature (in addition to $j\left(\mathrm{NO}_{2}\right)$ and $j\left(\mathrm{O}^{1} \mathrm{D}\right)$ ) implies that photolytic sources active at longer wavelengths (e.g., photosensitized conversion of $\mathrm{NO}_{2}$ on organic surfaces (Stemmler et al., 2006) or photolysis of nitro aromatic compounds (Bejan et al. (2006)) or those that are $j\left(\mathrm{O}^{1} \mathrm{D}\right)$ dependent, e.g., the photolysis of $\mathrm{HNO}_{3}$ (Zhou et al., 2003, 2011) or those that are temperature dependent (Su et al., 2011), are all of significance. Despite that these results leave the question of unknown HONO daytime sources open, they offer linear regression equations that can be used as an indicator for unknown HONO production within the range of conditions investigated (i.e., at a $\mathrm{HONO} / \mathrm{NO}_{\mathrm{x}}$ ratio $>0.02$ ).

Interestingly, the unidentified HONO sources were found to correlate inversely with $j\left(\mathrm{NO}_{2}\right), j\left(\mathrm{O}^{1} \mathrm{D}\right)$ and temperature (see Fig. 9). The highest absolute values of the unidentified sources are estimated during the winter season in Santiago_W, under highly polluted conditions, coinciding with lower actinic fluxes and temperatures, compared to Santiago_S, followed by HOxComp. Veitel (2002) showed that nocturnal HONO mixing ratios directly correlate to Radon, especially in winter. He also measured the highest HONO mixing ratios of $2.4 \mathrm{ppb}$ at night in January (1999) coinciding with very high Radon levels. Thus, Veitel (2002) concluded that surfaces at or near the ground form the most prominent HONO source both by day and night. Similarly, Febo et al. (1999) stated that especially trace gases emitted or formed near the ground show a direct and strong correlation with Radon. Their results agree with our findings that unidentified sources are mainly ground-based with highest contributions in the winter season. The negative slopes obtained in Fig. 9 should not be confused with the positive slopes obtained in Elshorbany et al. (2009a, 2012) as the latter were obtained independently in each study (i.e., under the same atmospheric 

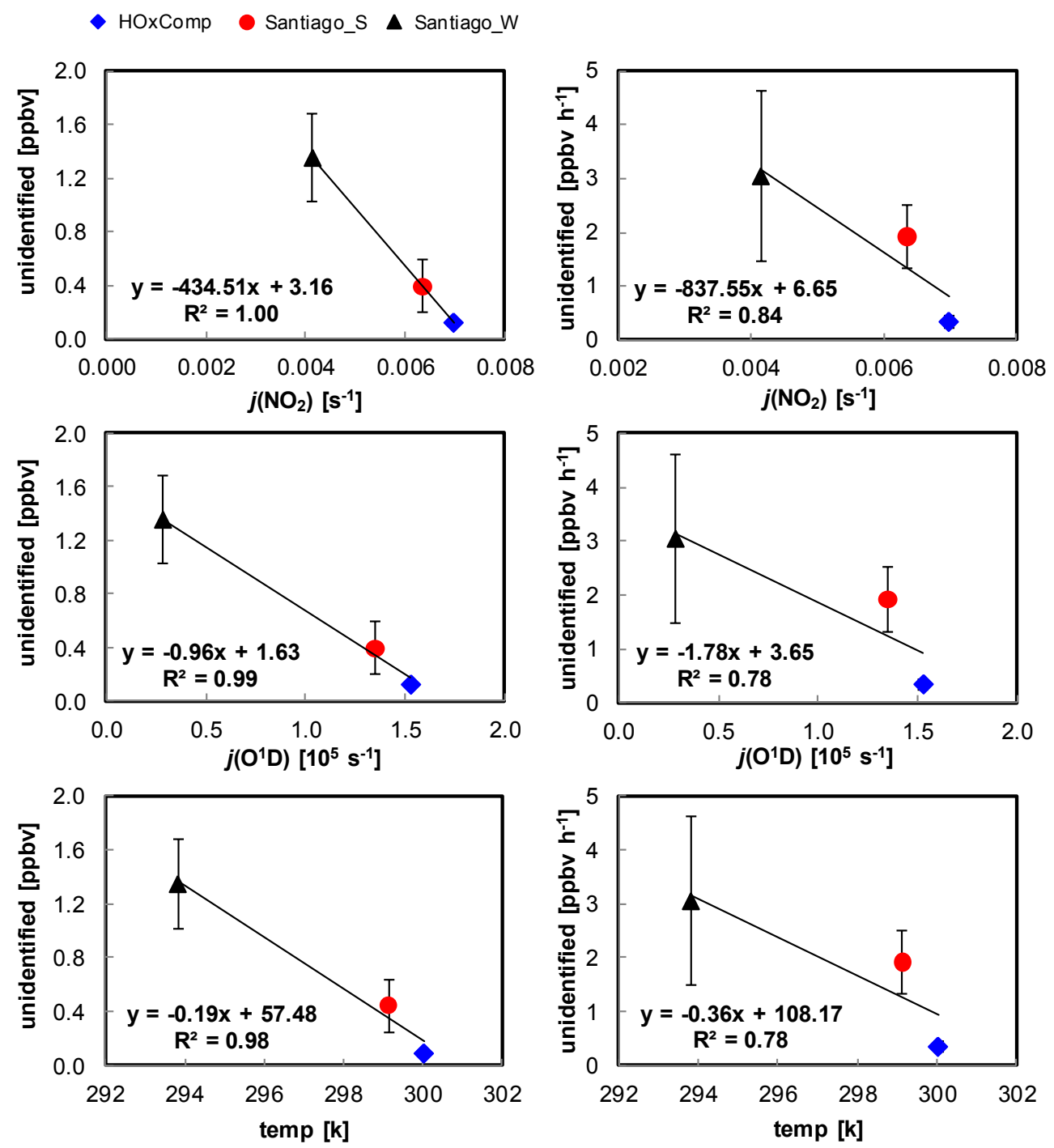

Fig. 9. Correlation between unidentified HONO mixing ratios and their source strength versus $j\left(\mathrm{NO}_{2}\right), j\left(\mathrm{O}^{1} \mathrm{D}\right)$ and temperature observed in field measurement campaigns with a $\mathrm{HONO} / \mathrm{NO}_{\mathrm{x}}$ ratio of $>0.02$. Error bars represent $1 \sigma$ of the mean.

conditions) and therefore may only relate to the similar diurnal cycle of $j\left(\mathrm{NO}_{2}\right)$ and the unidentified HONO sources (i.e., may not necessarily follow any physical dependency). The correlations in Fig. 9 are also quite interesting because they show that unidentified HONO sources during the afternoon can be directly calculated as a function of $j\left(\mathrm{NO}_{2}\right)$ or $j\left(\mathrm{O}^{1} \mathrm{D}\right)$ (also vs. temperature but with less accuracy) as follows:

Unidentified $\mathrm{HONO}\left(\mathrm{ppbvh}^{-1}\right)=$

$(-838 \pm 360) j\left(\mathrm{NO}_{2}\right)+(6.65 \pm 2.15)$,

Unidentified $\mathrm{HONO}\left(\mathrm{ppbvh}^{-1}\right)=$

$(-1.78 \pm 0.94) \times 10^{5} j\left(\mathrm{O}^{1} \mathrm{D}\right)+(3.65 \pm 1.12)$

Indeed, considering an estimated daytime average $j\left(\mathrm{NO}_{2}\right)$ for Xinken, China (PRIDEPRD2004) and Back Garden, China (PRIDE-PRD2006) of about 0.005 and $0.007 \mathrm{~s}^{-1}$, the approximate unidentified HONO source strength based on the relationship (Eq. 7) would be about $2.5 \pm 1.1$ and $0.78 \pm 0.34 \mathrm{ppbh}^{-1}$, respectively which is in good agreement with those reported by Li et al. (2012). Nevertheless, since the above correlations were derived based on a limited number of measurement campaigns, further evaluation is required.

\subsubsection{Measured vs simulated HONO levels}

Figure 10 shows the correlations between measured and simulated HONO mixing ratios based on equations (Eq. 1) to (Eq. 6) and the mean $\mathrm{HONO} / \mathrm{NO}_{\mathrm{x}}$ ratio of 0.02 for all investigated measurement campaigns. It appears that measured HONO diurnal profiles for all campaigns can be simulated quite well for both $24 \mathrm{~h}$ and daytime averages with 

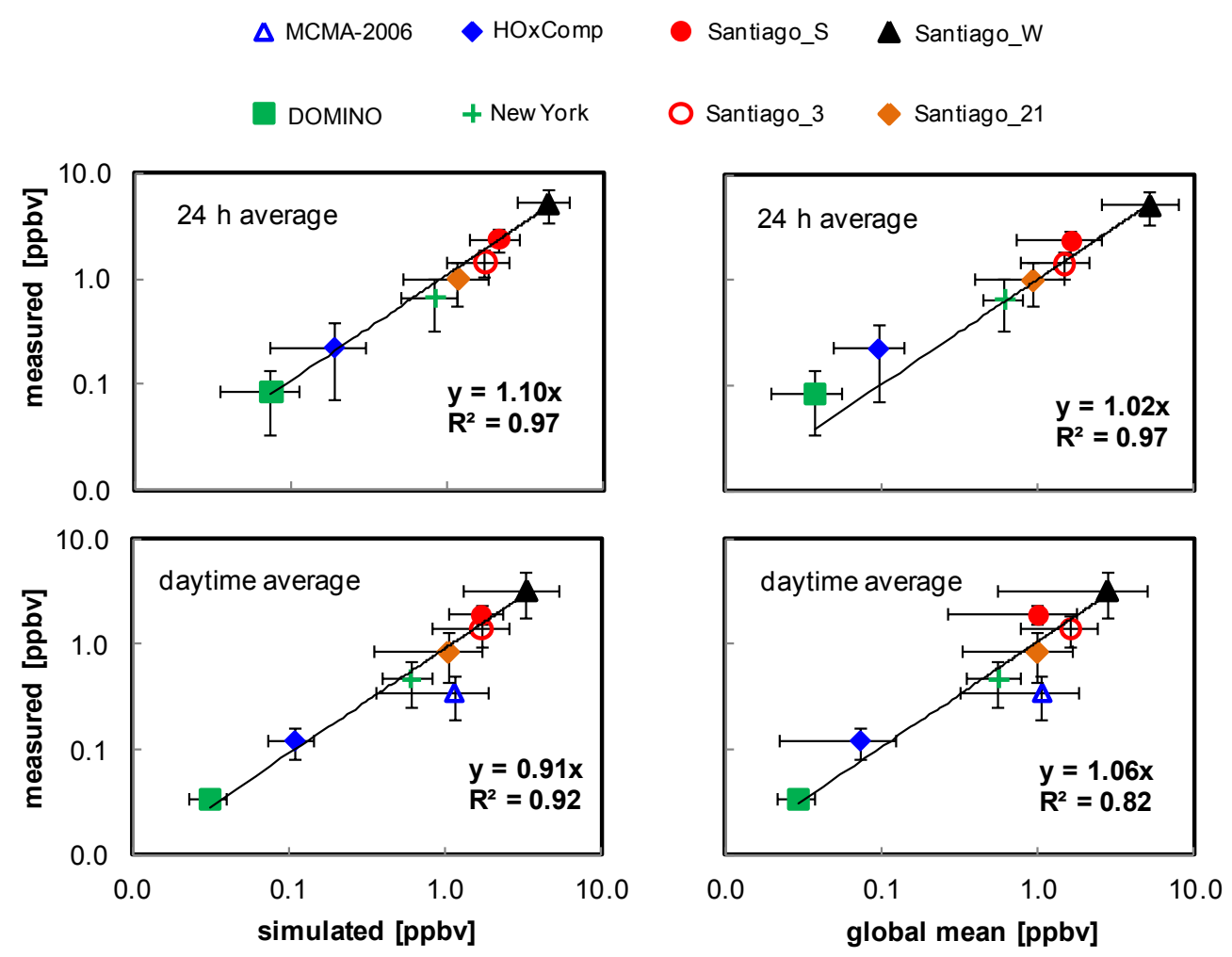

Fig. 10. Correlations between measured and calculated HONO mixing ratios for $24 \mathrm{~h}$ (upper panel) and daytime averages (lower panel) based on the HONO/NO${ }_{\mathrm{x}}$ dependency (simulated, left panel, see text for details) and that calculated using the mean $\mathrm{HONO} / \mathrm{NO}_{\mathrm{x}}$ ratio of 0.02 (global mean, right panel) for the different measurement campaigns. Error bars represent $1 \sigma$ of the mean.

a linear measured/simulated regression slope of $1.10 \pm 0.05$ and $0.91 \pm 0.07$, respectively. Similar agreement is also obtained between measured and calculated HONO mixing ratios using the mean $\mathrm{HONO} / \mathrm{NO}_{\mathrm{x}}$ ratios of 0.02 with slopes of $1.02 \pm 0.05$ and $1.06 \pm 0.13$, respectively, albeit with lower correlation coefficients, which is due to the underestimation of measured HONO mixing ratios during the afternoon for measurement campaigns with $\mathrm{HONO} / \mathrm{NO}_{\mathrm{x}}$ ratios $>0.02$ (see Sect. 3.2.2). This can only be accounted for by equation (Eq. 6). However, the calculation of afternoon HONO mixing ratios using (Eq. 6) requires the prior knowledge of the $\mathrm{HONO} / \mathrm{NO}_{\mathrm{x}}$ ratio (see Sect. 3.2.2), which is not feasible for a prognostic method. In addition, during daytime the slope of the relationship between $\mathrm{HONO}$ and $\mathrm{NO}_{\mathrm{x}}$ for all measurement campaigns is $0.022 \pm 0.002$, which is quite similar to the overall mean $\mathrm{HONO} / \mathrm{NO}_{\mathrm{x}}$ ratio. Therefore, the overall mean $\mathrm{HONO} / \mathrm{NO}_{\mathrm{x}}$ ratio of 0.02 is considered to be most suitable to approximate the HONO mixing ratios and investigate the global impact of HONO photolysis during daytime on $\mathrm{HO}_{\mathrm{x}}$ and $\mathrm{O}_{3}$ chemistry.

\subsection{Global impact}

In global models HONO is typically simulated based on the known gas phase chemistry (i.e., only accounting for
[HONO]pss, see Sect. 3.2.2), thus significantly underestimating ambient $\mathrm{HONO}$ concentrations. Consequently, $\mathrm{HO}_{\mathrm{x}}, \mathrm{O}_{3}$ and other secondary oxidation products from HONO photolysis during daytime are also expected to be significantly underestimated. Since most polluted regions with high $\mathrm{NO}_{\mathrm{x}}$ levels are located in the Northern Hemisphere, the impact of using more realistic HONO levels should be most pronounced in this part of the world, where NO levels are often sufficient for efficient radical recycling (Lelieveld et al., 2002; Elshorbany et al., 2010b). To investigate the impacts by HONO photolysis, including the seasonal dependency, we focus on model output for the months June and December. The global mean $\mathrm{HONO} / \mathrm{NO}_{\mathrm{x}}$ ratio of 0.02 , empirically derived from the correlation between $\mathrm{HONO}$ and $\mathrm{NO}_{\mathrm{x}}$ has been implemented in the EMAC model. In addition, the sensitivity runs $\mathrm{S} 1$ and $\mathrm{S} 3$ apply differences by a factor of two, thus using $\mathrm{HONO} / \mathrm{NO}_{\mathrm{x}}$ ratios of 0.01 and 0.04 , respectively.

As shown in Fig. 11, simulated HONO levels based on a $\mathrm{HONO} / \mathrm{NO}_{\mathrm{x}}$ ratio of $0.02(\mathrm{~S} 2)$ are typically more than order of magnitude higher than those simulated by the base run, which considers only gas phase HONO formation (i.e., $\mathrm{OH}+\mathrm{NO} \rightarrow \mathrm{HONO}$ ). These results are in agreement with $\mathrm{Li}$ et al. (2010), Zhang et al. (2011) and Czader et al. (2012) who also showed that measured HONO mixing ratios are about tenfold of those calculated when this reaction is the 

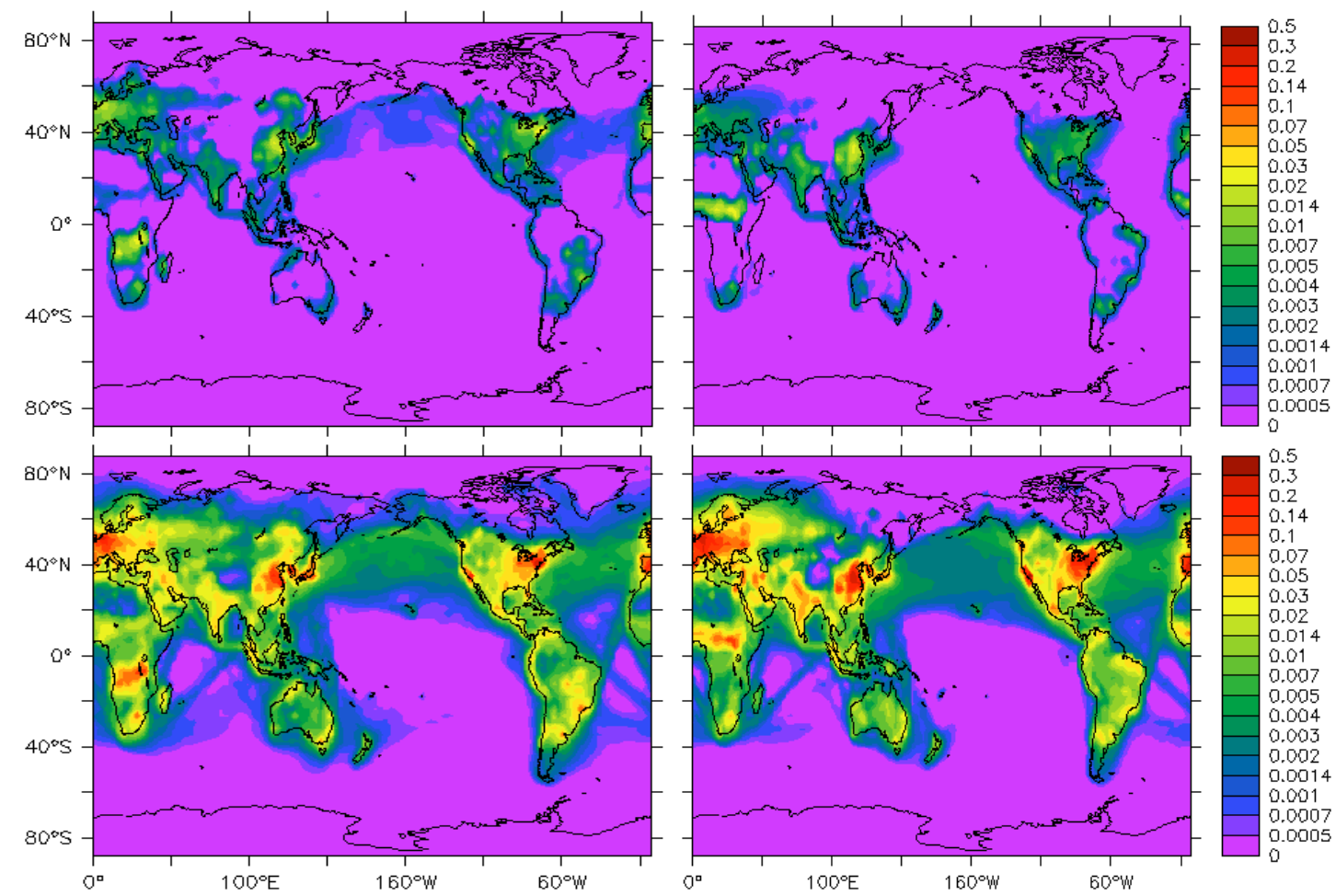

Fig. 11. Simulated monthly average HONO mixing ratio near the surface in ppbv for the base (upper panel) and S2 (lower panel) scenarios in June (left) and December (right).
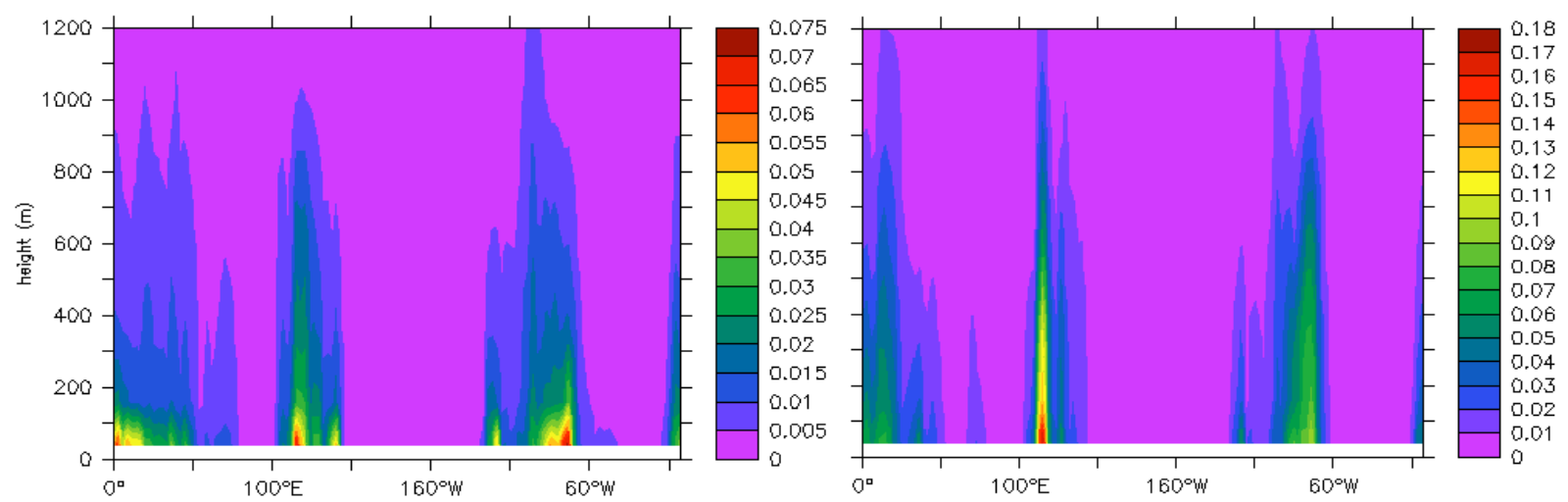

Fig. 12. Simulated one day average HONO mixing ratios (ppbv), averaged over the Northern Hemisphere $\left(30^{\circ} \mathrm{N}\right.$ to $\left.50^{\circ} \mathrm{N}\right)$ during summer (on 29 June 2005, left) and winter (on 30 December, 2005, right) within the first $1200 \mathrm{~m}$ above the ground.

only formation mechanism. The simulated HONO levels in the S2 run in December are higher than those during June, which is also in good agreement with previous studies, showing that HONO levels in winter are higher than in summer (e.g., Elshorbany et al., 2010a). The simulated HONO levels in June in South Korea and in December in east China compare well to those measured during May-July 2005 in Seoul (Korea) and during Oct-Jan 2004/2005 in Shanghai (China) (Li et al., 2012, and references therein). Furthermore, the day $(24 \mathrm{~h})$ average HONO mixing ratios, averaged over the Northern Hemisphere (from $30^{\circ} \mathrm{N}$ to $50^{\circ} \mathrm{N}$ ) show a clear gradient within the first $1200 \mathrm{~m}$ above the ground (i.e., the lowest model layer is centred at $\sim 30 \mathrm{~m}$ ), both in summer (on 29 June, 2005) and winter (on 30 December, 2005), being most apparent in highly polluted regions, especially in summer (see Fig. 12). These results are in agreement with HONO gradient measurements in previous studies (Volkamer et al., 2010; Vellina et al., 2011; Wong et al., 2011, 2012).

Figure 13 shows that the shape of the simulated diurnal HONO profile on 10 July 2005, in Northwest Germany $\left(50.93^{\circ} \mathrm{N}, 6.36^{\circ} \mathrm{E}\right)$ using the base model, differs strongly from the observations during the HOxComp and 

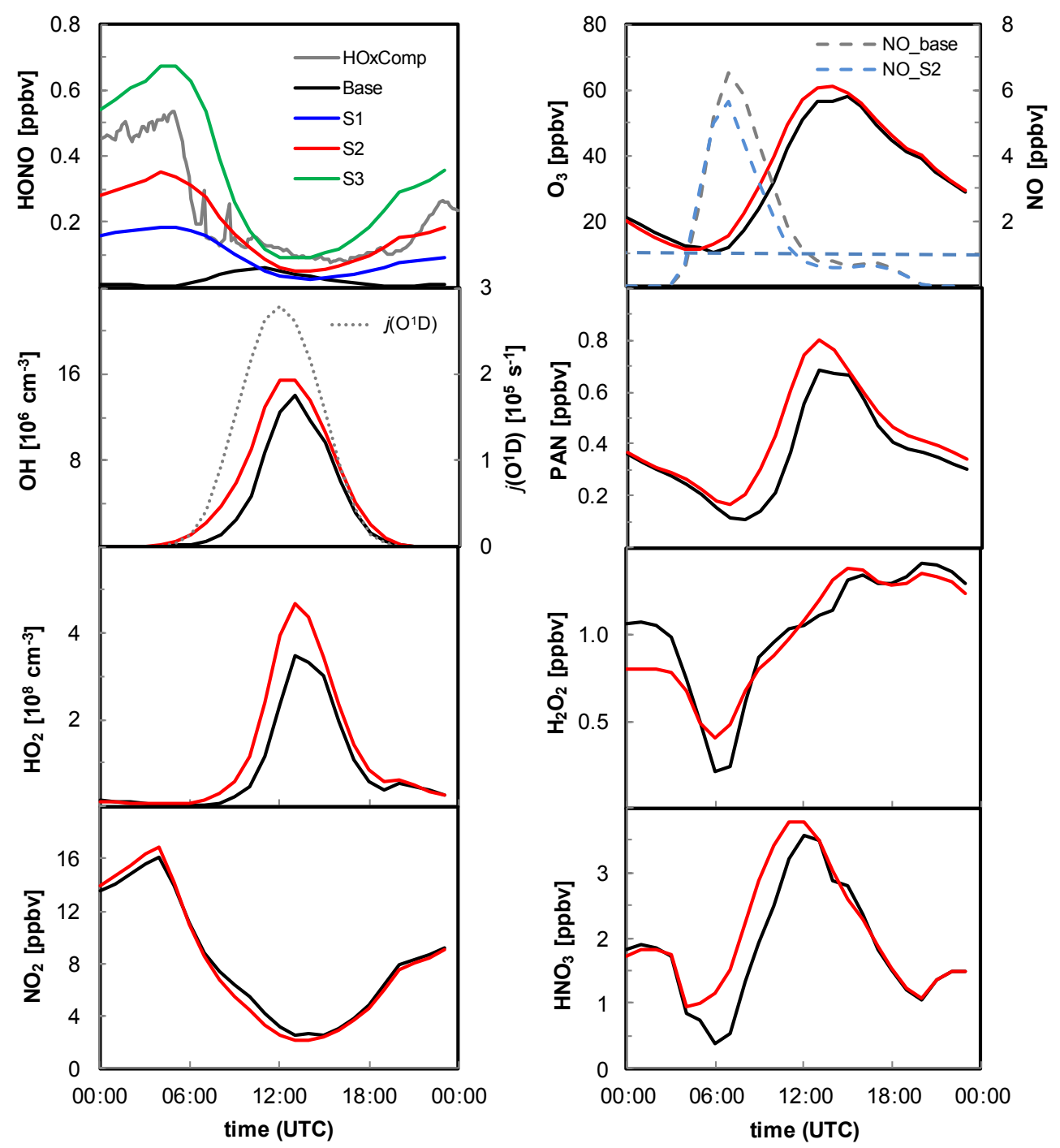

Fig. 13. Simulated diurnal cycles for 10 July 2005, in Northwest Germany $\left(50.93^{\circ} \mathrm{N}, 6.36^{\circ} \mathrm{E}\right)$ compared to the measured HONO diurnal profile during the HOxComp campaign near Jülich in Germany $\left(50.91^{\circ} \mathrm{N}, 6.41^{\circ} \mathrm{E}\right.$, from Elshorbany et al., 2012).

other campaigns presented in Fig. 1. Owing to the coarse spatial resolution of the model the profiles in Fig. 13 represent larger areas than the measurements, though the agreement is rather good, probably indicating that HOxComp is representative of this area. In contrast to the base scenario, the shape of the simulated HONO diurnal profiles, $\mathrm{S} 1, \mathrm{~S} 2$ and $\mathrm{S} 3$ based on the HONO/NO $\mathrm{N}_{\mathrm{x}}$ ratios of $0.01,0.02$ and 0.04 , respectively match the measurements much better with maximum HONO mixing ratios during the early morning and minimum values during afternoon. The simulated HONO by the $\mathrm{S} 2$ run (based on a $\mathrm{HONO} / \mathrm{NO}_{\mathrm{x}}$ ratio of 0.02 ) agrees best with the measurements. These results corroborate our earlier conclusion that simulating $\mathrm{HONO}$ based on a mean $\mathrm{HONO} / \mathrm{NO}_{\mathrm{x}}$ ratio of 0.02 provides a realistic representation of $\mathrm{HONO}$, rather than considering only the gas phase formation of HONO. Therefore, the $\mathrm{S} 2$ run is used hereafter to investigate the impact of implementing this more realistic HONO parameterization. As also shown in Fig. 13, enhancements in $\mathrm{OH}, \mathrm{HO}_{2}, \mathrm{O}_{3}$, PAN, $\mathrm{H}_{2} \mathrm{O}_{2}, \mathrm{NO}_{\mathrm{x}}$ and $\mathrm{HNO}_{3}$ are calculated only at NO levels of about $1 \mathrm{ppbv}$ (marked by the dashed line in the diurnal NO profile). When NO levels are below 1 ppbv, enhancements are typically small or negligible. This is due to the low recycling efficiency (under NO sensitive conditions), under which any increase in the $\mathrm{OH}$ levels as a result of HONO photolysis does not lead to a significant increase in the $\mathrm{HO}_{2}$ levels from reaction $\left(\mathrm{RO}_{2}+\mathrm{NO} \rightarrow \mathrm{HO}_{2}\right), \mathrm{H}_{2} \mathrm{O}_{2}$ from the reaction of $\left(\mathrm{HO}_{2}+\mathrm{HO}_{2} \rightarrow \mathrm{H}_{2} \mathrm{O}_{2}\right)$ or $\mathrm{O}_{3}$ from the reaction of $\left(\mathrm{RO}_{2} / \mathrm{HO}_{2}+\mathrm{NO} \rightarrow \mathrm{NO}_{2} \rightarrow \mathrm{O}_{3}\right)$. These results show that an increase in the $\mathrm{HO}_{\mathrm{x}}$ levels as well as in the secondary oxidation products only occurs under conditions of efficient recycling of $\mathrm{OH}$ through $\mathrm{RO}_{2} / \mathrm{HO}_{2}$, in agreement with the sensitivity analysis performed for HOxComp (Elshorbany et 

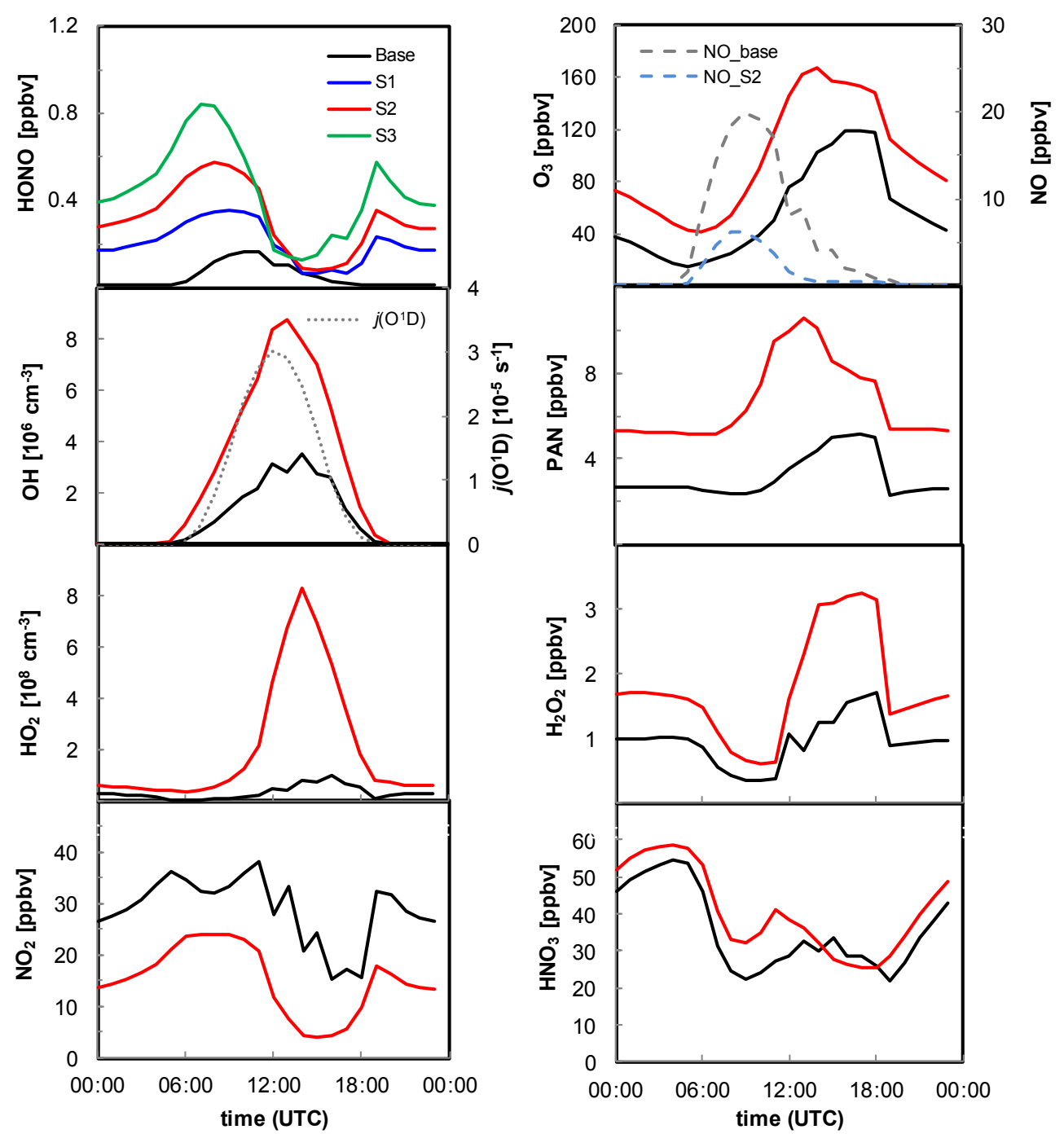

Fig. 14. Simulated diurnal cycles in the eastern USA $\left(40.5^{\circ} \mathrm{N}, 73.1^{\circ} \mathrm{W}\right)$ on 1 June 2005.

al., 2012). The enhancement of $\mathrm{HO}_{\mathrm{x}}$ as a result of applying higher HONO values also leads to a redistribution of model calculated reactive nitrogen compounds. For example, the increased levels of $\mathrm{OH}, \mathrm{HO}_{2}$ and other secondary oxidation products (e.g., acyl peroxy radicals $\left(\mathrm{RC}(\mathrm{O}) \mathrm{O}_{2}\right)$ ) may reduce $\mathrm{NO}_{2}$ (e.g., $\mathrm{OH}+\mathrm{NO}_{2} \rightarrow \mathrm{HNO}_{3}, \mathrm{RC}(\mathrm{O}) \mathrm{O}_{2}+\mathrm{NO}_{2} \rightarrow \mathrm{PAN}$ ) and $\mathrm{NO}$ (e.g., $\mathrm{HO}_{2}+\mathrm{NO} \rightarrow \mathrm{OH}+\mathrm{NO}_{2}$ ) forming $\mathrm{HNO}_{3}$ and PAN. As shown in Fig. 13, the additional daytime HONO leads to a decrease in $\mathrm{NO}$ and $\mathrm{NO}_{2}$, while $\mathrm{HNO}_{3}$ and PAN increase during the high $\mathrm{NO}_{\mathrm{x}}$ period. During daytime (06:0018:00 UTC), $\mathrm{NO}, \mathrm{NO}_{2}, \mathrm{OH}, \mathrm{HO}_{2}, \mathrm{O}_{3}, \mathrm{PAN}, \mathrm{H}_{2} \mathrm{O}_{2}$ and $\mathrm{HNO}_{3}$ change by $-19,-9,36,45,10,26,2$ and $19 \%$, respectively in the $\mathrm{S} 2$ run compared to the base model, in agreement with previous studies (e.g. Li et al., 2011).

To further investigate the impact of the more realistic HONO levels in relatively polluted areas (high- $\mathrm{NO}_{\mathrm{x}}$, VOClimited conditions), Fig. 14 compares the simulated diurnal profiles in the eastern USA and downwind on 1 June 2005. It appears that the shape of the simulated diurnal HONO profiles from the runs S1, S2 and S3 match well to those measured in field campaigns (see Fig. 1), in contrast to the base scenario. As shown in Fig. 14, significant increases in $\mathrm{HO}_{\mathrm{x}}$ and the secondary oxidation products result from the more realistic HONO levels (simulated by S2). Unfortunately, no $\mathrm{HONO}$ field measurements are available for comparison in this area for 2005. The simulated maximum $\mathrm{O}_{3}$ levels (S2) agree with the reported levels in New York State in 2005 (New York State Department of Environmental Conservation). Similar to the HOxComp case, $\mathrm{NO}$ and $\mathrm{NO}_{2}$ decrease while $\mathrm{HO}_{\mathrm{x}}, \mathrm{O}_{3}, \mathrm{PAN}, \mathrm{H}_{2} \mathrm{O}_{2}$ and $\mathrm{HNO}_{3}$ increase, with higher relative enhancements compared to HOxComp, owing to the relatively high $\mathrm{NO}_{\mathrm{x}}$ conditions during daytime (see Fig. 14). These results underscore that the more realistic representation of HONO in a global model leads to an enhancement in simulated $\mathrm{HO}_{\mathrm{x}}$ and oxidation products, predominantly under high $\mathrm{NO}_{\mathrm{x}}$ conditions. 

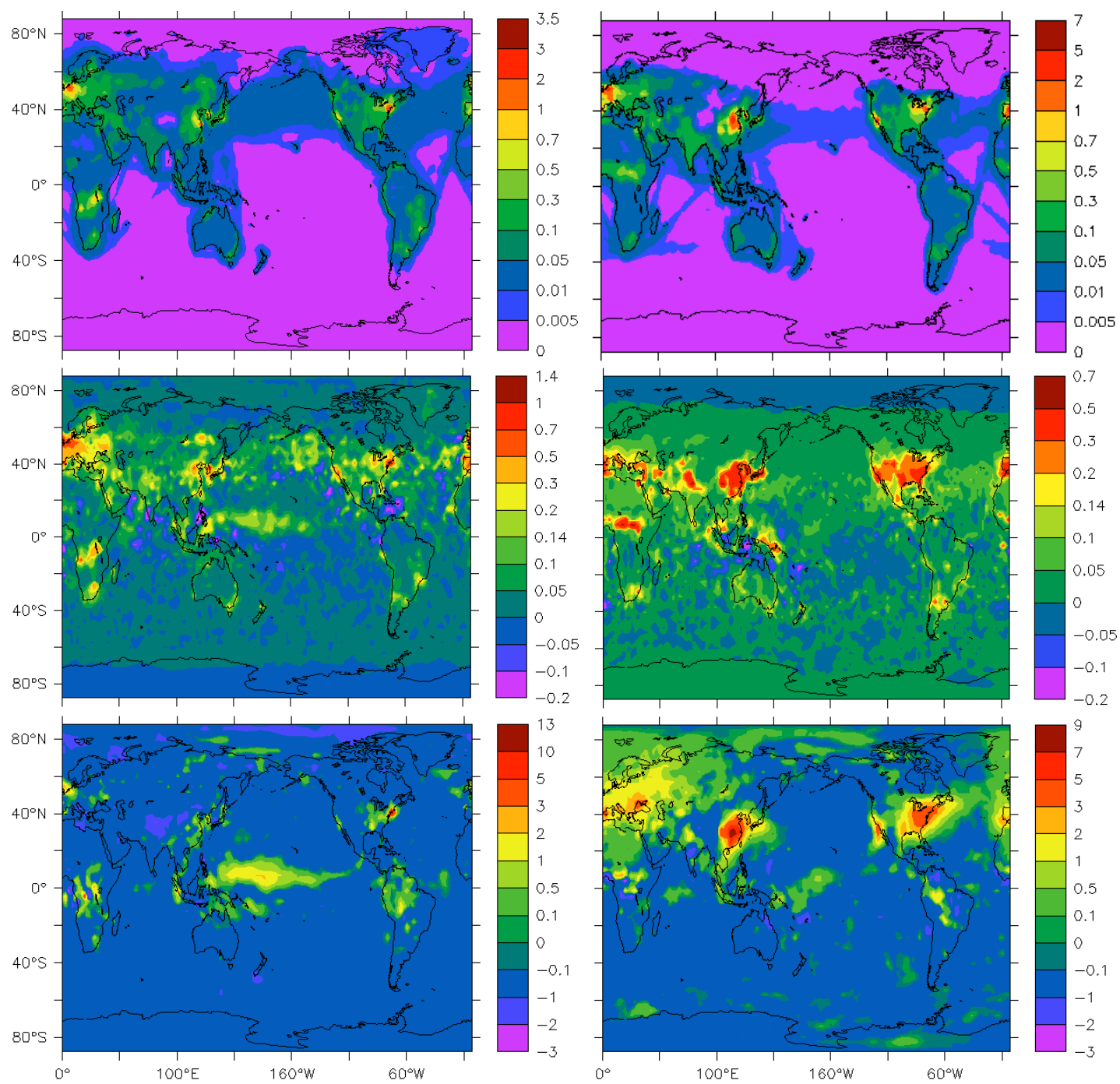

Fig. 15. Simulated monthly average enhancement of $\mathrm{OH}$ (middle panel, $10^{6}$ molecules $\mathrm{cm}^{-3}$ ) and ozone (lower panel, ppbv) near the surface, indicating the difference between the $\mathrm{S} 2$ and base scenarios as a function of NO (base scenario, upper panel, ppbv) in June (left) and December (right).

Figures 15 and 16 show the absolute and relative enhancements, respectively, in $\mathrm{OH}$ and $\mathrm{O}_{3}$ together with simulated NO levels. As shown in Fig. 15, in the relatively polluted Northern Hemisphere average monthly NO mixing ratios in December are typically two times higher than in June. In addition, in June NO levels are relatively high in the northeastern USA and in northern Europe, e.g., in comparison to eastern China. Consequently, the enhancements of $\mathrm{OH}$ and $\mathrm{O}_{3}$ levels are relatively strong in these high- $\mathrm{NO}_{\mathrm{x}}$ regions. Also, over eastern China in December where NO levels are higher than in the USA and Europe, the enhancements of $\mathrm{OH}$ and $\mathrm{O}_{3}$ levels are larger. In addition, the relative enhancements of $\mathrm{OH}$ and $\mathrm{O}_{3}$ are significantly higher in the winter hemisphere compared to summer (see Fig. 16). Similarly, previous studies showed that the impact of HONO photolysis on $\mathrm{OH}$ is higher in winter than in summer (Aumont, 2003;
Elshorbany et al., 2010a), owing to the relatively minor importance of the other photochemical sources such as $\mathrm{O}_{3}$ and HCHO (Elshorbany et al., 2010b), in addition to the higher NO levels in winter. Thus, the increased HONO levels in the model significantly enhance the oxidation capacity in polluted regions, especially in winter, when other photolytic $\mathrm{OH}$ sources are of minor importance.

Figures 17 and 18 show some details of the modelcalculated enhancement in $\mathrm{OH}, \mathrm{O}_{3}, \mathrm{NO}_{\mathrm{x}}, \mathrm{HNO}_{3}$ and PAN over the eastern USA in June and eastern China in December, together with the NO mixing ratios (top panels in Fig. 17). It is evident that the relative enhancements in these species follow the relative changes in NO. In these high- $\mathrm{NO}_{\mathrm{x}}$ regions, monthly average $\mathrm{OH}$ enhancements up to about $1.5 \times 10^{6}$ and $0.6 \times 10^{6}$ molecules $\mathrm{cm}^{-3}$ are calculated for June and December 2005, respectively, while $\mathrm{O}_{3}$ is calculated to increase up 

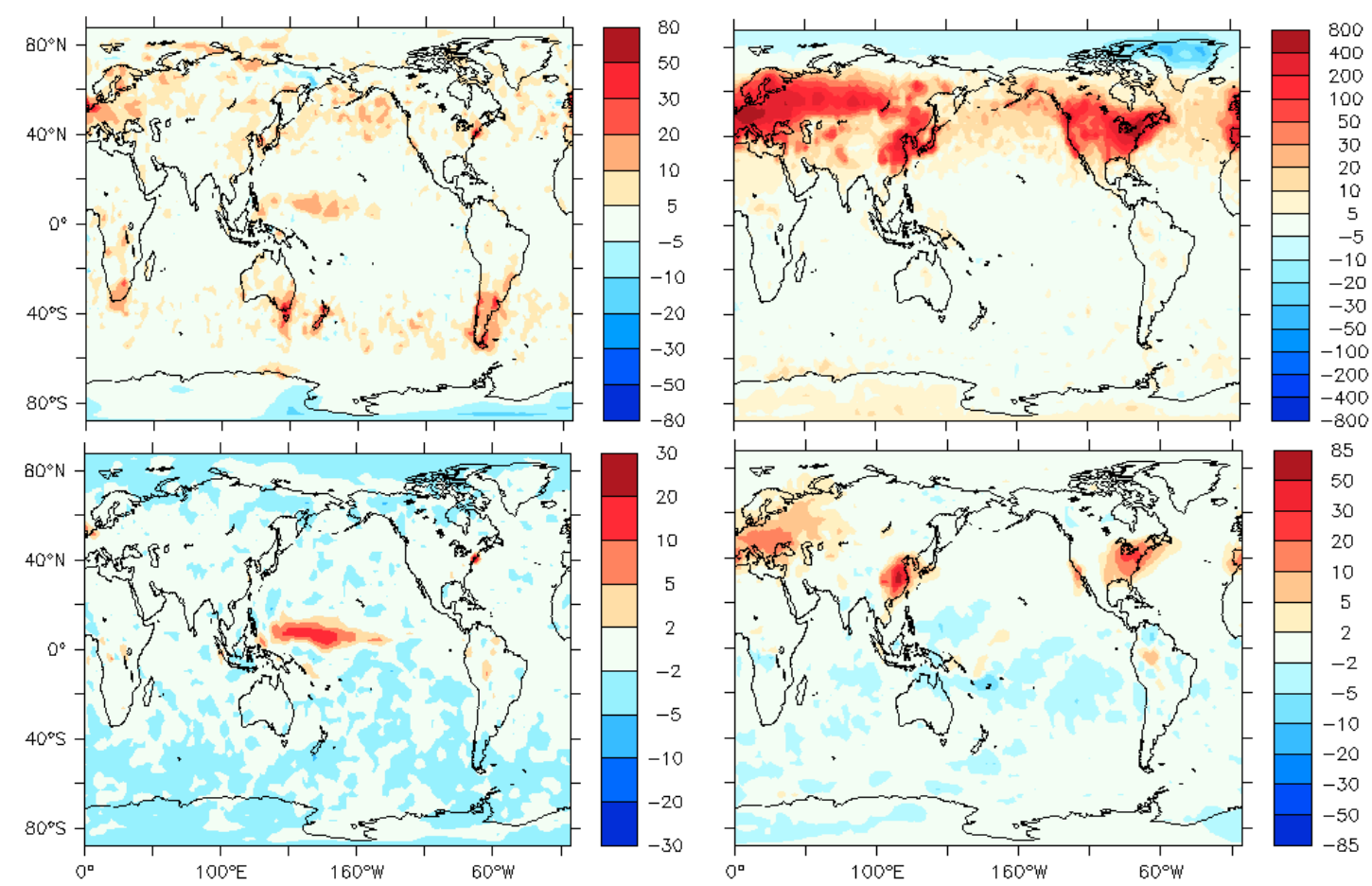

Fig. 16. Monthly average relative enhancements (in \%) in $\mathrm{OH}$ (upper panel) and ozone (lower panel) near the surface, indicating the difference between the $\mathrm{S} 2$ and base scenarios (relative to the latter) in June (left) and December (right).

to 12 and $8.5 \mathrm{ppbv}$, respectively. These increases are highly significant, corresponding to relative $\mathrm{OH}$ and $\mathrm{O}_{3}$ enhancements of about 80 and $30 \%$ in June and about 90 and $40 \%$ in December, respectively. These results are quite comparable to those in previous studies for specific locations applying small-scale models. For example, model simulations of daytime HONO in Mexico City, which could only account for about $30-50 \%$ of the observed HONO, indicate an average midday $\mathrm{O}_{3}$ enhancement of $6 \mathrm{ppbv}$ ( $\mathrm{Li}$ et al., 2010). Similarly, $\mathrm{Li}$ et al. (2011) reported an average $\mathrm{O}_{3}$ enhancement of $12 \mathrm{ppbv}(\sim 50 \%)$ compared to the base case considering only gas phase HONO formation. These results are also in good agreement with Elshorbany et al. (2009b) who compared box model calculations constrained by measured $\mathrm{HONO}$ to those only considering $\mathrm{OH}+\mathrm{NO} \rightarrow \mathrm{HONO}$. In the latter case, $\mathrm{O}_{3}$ levels decreased on average by $30 \%$ during daytime. Similarly, Harris et al. (1982) and Clapp and Jenkin (2001), employing photochemical trajectory models, showed that HONO photolysis may have an important impact on the level of oxidants mostly under polluted high- $\mathrm{NO}_{\mathrm{x}}$ conditions. Jorba et al. (2012) also showed that $\mathrm{O}_{3}$ levels are enhanced in response to additional $\mathrm{OH}$ production only in high- $\mathrm{NO}_{\mathrm{x}}$ regions though can be decreased in regions under low- $\mathrm{NO}_{\mathrm{x}}$ conditions.

These results thus illustrate that the $\mathrm{HONO} / \mathrm{NO}_{\mathrm{x}}$ ratio is a reasonable proxy to simulate HONO levels in global models, thus avoiding the strong underestimation of HONO concentrations, with consequences for simulated $\mathrm{HO}_{\mathrm{x}}$ and sec- ondary oxidation products. In view of the many unknowns and uncertainties about daytime HONO sources, global models could apply this method until the chemistry of HONO is resolved in greater detail.

\section{Conclusions}

$\mathrm{HONO}, \mathrm{NO}_{\mathrm{x}}$ and auxiliary atmospheric chemistry parameters have been investigated using data from 15 field measurement campaigns around the globe (from $52^{\circ} \mathrm{N}$ to $33^{\circ} \mathrm{S}$ and from $116^{\circ} \mathrm{E}$ to $99^{\circ} \mathrm{W}$ ). The high correlation between HONO and $\mathrm{NO}_{\mathrm{x}}$ in all data sets reveals a robust and consistent linear regression slope of $0.02 \pm 0.002$. Our analysis indicates that, given the ambient $\mathrm{NO}_{\mathrm{x}}$ mixing ratio, the $\mathrm{HONO} / \mathrm{NO}_{\mathrm{x}}$ ratio is a suitable proxy of $\mathrm{HONO}$ mixing ratios both during night and daytime. It should be mentioned, however, that owing to the limited number of field measurements and the large uncertainties associated with HONO measurements under very low $\mathrm{NO}_{\mathrm{x}}$ and $\mathrm{HONO}$ conditions, i.e., remote from pollution sources such as high altitude and polar regions, the obtained average $\mathrm{HONO} / \mathrm{NO}_{\mathrm{x}}$ ratio of 0.02 should be applied with caution. Additional $\mathrm{HONO}$ and $\mathrm{NO}_{\mathrm{x}}$ measurements with improved measurement techniques (i.e, avoiding or correcting for interferences) under these conditions are needed to further evaluate the findings presented in this paper

For nighttime conditions, we derive a linear regression slope of $0.02 \pm 0.001$ based on all investigated campaigns. 

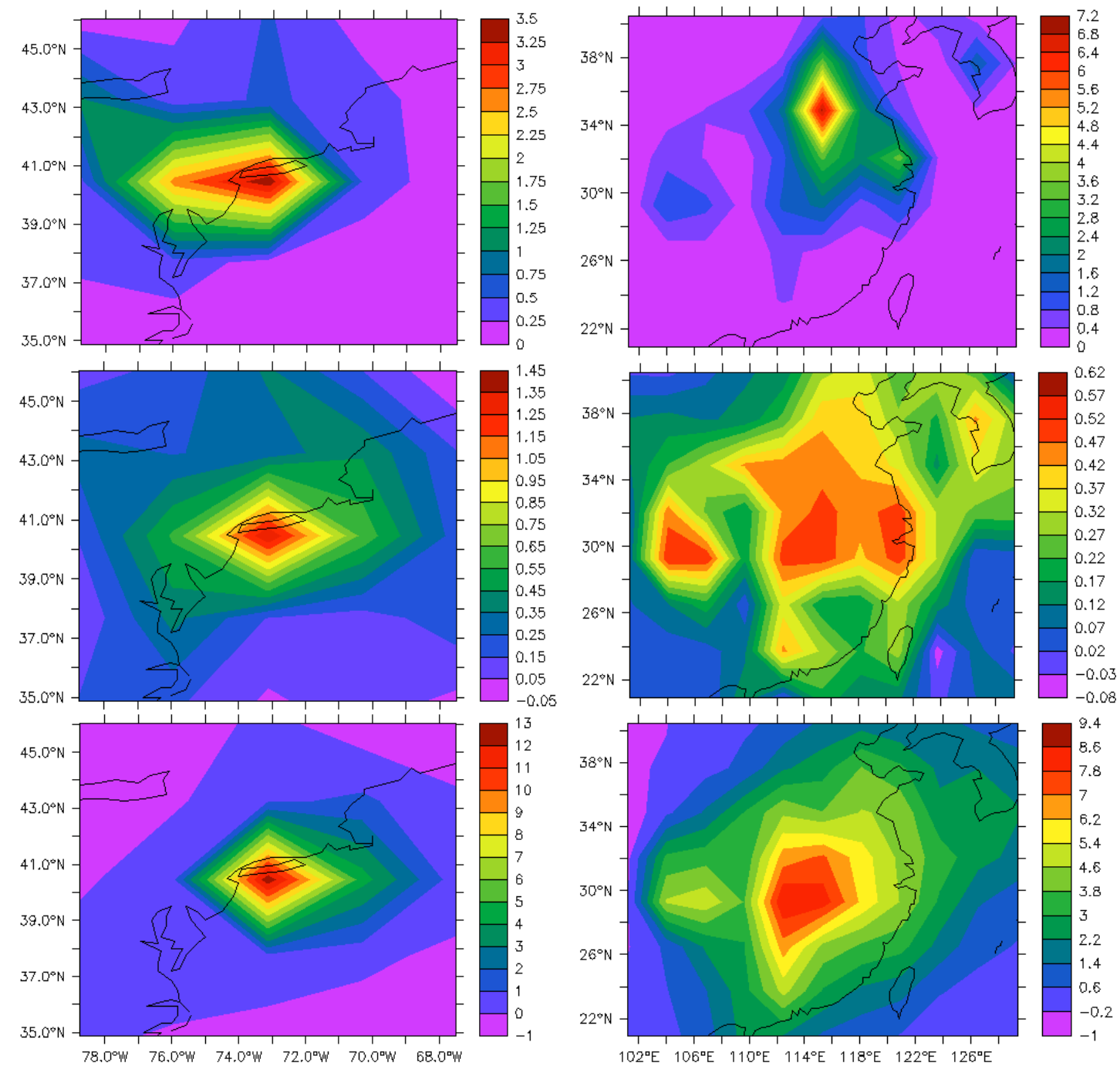

Fig. 17. Simulated monthly average enhancement of $\mathrm{OH}$ (middle panel, $10^{6}$ molecules $\mathrm{cm}^{-3}$ ) and $\mathrm{O}_{3}$ (lower panel, ppbv) near the surface as a function of NO (base scenario, upper panel, ppbv) in June over the eastern USA (left) and December over eastern China (right).

The HONO/NO ratio itself appears to follow a logarithmic relationship with $\mathrm{NO}_{\mathrm{x}}$, which can be explained by the nighttime heterogeneous formation of HONO. This is corroborated by the $\mathrm{HONO} / \mathrm{NO}_{\mathrm{x}}$ dependence on wind speed. In addition, the regression slope of the $\mathrm{HONO} / \mathrm{NO}_{\mathrm{x}}$ ratio versus $\mathrm{NO}_{\mathrm{x}}$ is different during both nighttime sectors $\mathrm{A}$ (midnight to sunrise) and D (sunset to midnight), from which the HONO concentration can be calculated as a function of $\mathrm{NO}_{\mathrm{x}}$ levels.

During daytime, a similar regression slope of $0.02 \pm 0.002$ between measured $\mathrm{HONO}$ and $\mathrm{NO}_{\mathrm{x}}$ mixing ratios is obtained for all investigated measurement campaigns. However, in contrast to nighttime conditions, the $\mathrm{HONO} / \mathrm{NO}_{\mathrm{x}}$ ratio is independent of $\mathrm{HONO}$ and $\mathrm{NO}_{\mathrm{x}}$ mixing ratios, in agreement with previous studies. The correlations between [HONO]pss and $\mathrm{NO}_{\mathrm{x}}$ during time sector $\mathrm{B}$ (sunrise to noon) as well as during daytime (time sectors $\mathrm{B}+\mathrm{C}$ ) reveal a similar regression slope of 0.014 , implying comparable contributions dur- ing both time sectors $\mathrm{B}$ and $\mathrm{C}$. In contrast, the correlations between unidentified $\mathrm{HONO}$ and $\mathrm{NO}_{\mathrm{x}}$ mixing ratios during the time sector B reveal a regression slope of 0.007 , much lower than the 0.011 obtained for daytime, implying higher contributions by unidentified sources during the afternoon, also in agreement with previous studies. In contrast to time sector $\mathrm{B}$, the correlation between $\mathrm{HONO}$ and $\mathrm{NO}_{\mathrm{x}}$ during sector $\mathrm{C}$ (noon to sunset) results in two different correlation slopes. For measurement campaigns with $\mathrm{HONO} / \mathrm{NO}_{\mathrm{x}}$ ratios $\leq 0.02$, a regression slope of $0.017 \pm 0.003$ is obtained, while measurement campaigns with $\mathrm{HONO} / \mathrm{NO}_{\mathrm{x}}$ ratios $>0.02$ follow a regression slope of $0.042 \pm 0.01$. These results imply that for conditions with $\mathrm{HONO} / \mathrm{NO}_{\mathrm{x}}$ ratios $\leq 0.02$, HONO mixing ratios during time sector $\mathrm{C}$ are largely represented by [HONO]pss, with small additional contributions by unidentified sources. A very high correlation $\left(R^{2}=\right.$ $0.99)$ between the $\mathrm{HONO} / \mathrm{NO}_{\mathrm{x}}$ ratio and $j\left(\mathrm{NO}_{2}\right)$ is obtained 

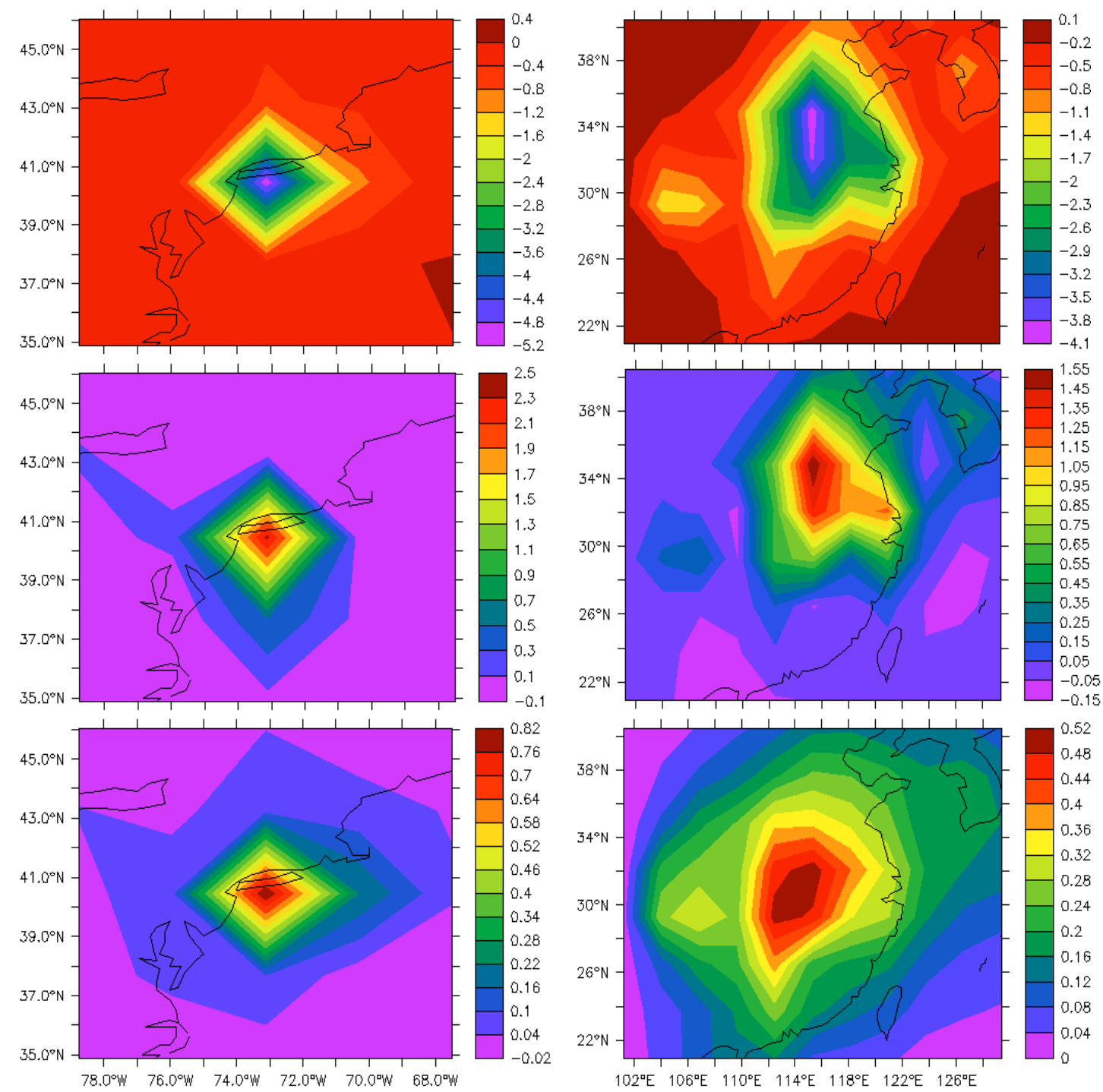

Fig. 18. Simulated monthly average enhancement of $\mathrm{NO}_{\mathrm{x}}$ (upper panel), $\mathrm{HNO}_{3}$ (middle panel) and PAN (lower panel) in ppbv near the surface in June over the eastern USA (left) and December over eastern China (right).

only for conditions with a $\mathrm{HONO} / \mathrm{NO}_{\mathrm{x}}$ ratio $>0.02$, while for those with $\mathrm{HONO} / \mathrm{NO}_{\mathrm{x}}$ ratios $\leq 0.02$, a much worse correlation $\left(R^{2}=0.44\right)$, even a negative slope is obtained. A potential explanation for this different $j\left(\mathrm{NO}_{2}\right)$ dependency is that during measurement campaigns with $\mathrm{HONO} / \mathrm{NO}_{\mathrm{x}}$ ratios $\leq 0.02$, unknown daytime HONO sources that are $j\left(\mathrm{NO}_{2}\right)$ dependent do not contribute significantly.

High correlations are also obtained between unidentified HONO and its source strength $\left(\mathrm{ppbh}^{-1}\right)$, and $j\left(\mathrm{NO}_{2}\right)$, $j\left(\mathrm{O}^{1} \mathrm{D}\right)$ and temperature for time sector $\mathrm{C}$ (noon to sunset). These results imply that photolytic sources active at longer wavelengths or those that are $j\left(\mathrm{O}^{1} \mathrm{D}\right)$ dependent are of significance. In fact these results suggest that sources that are solely temperature dependent may also be important, as predicted by Su et al. (2011). Interestingly, we also find that unidentified HONO sources correlate inversely with $j\left(\mathrm{NO}_{2}\right)$, $j\left(\mathrm{O}^{1} \mathrm{D}\right)$ and temperature, from which they can be estimated.

The mean $\mathrm{HONO} / \mathrm{NO}_{\mathrm{x}}$ ratio of 0.02 , derived from all measurement campaigns investigated, has been implemented into the EMAC chemistry-climate model to calculate the global HONO distribution. Strong HONO enhancements are predicted relative to the base model, which only accounts for the gas phase reaction of $\mathrm{OH}$ with NO. Reasonable agreement is obtained between simulated and measured HONO mixing ratios during both summer and winter. The simulated HONO mixing ratios appear to have a significant impact on $\mathrm{HO}_{\mathrm{x}}, \mathrm{O}_{3}$ and other oxidants, however, predominantly under polluted high- $\mathrm{NO}_{\mathrm{x}}$ conditions. Furthermore, the relative enhancements in $\mathrm{OH}$ and secondary products are higher in winter than in summer, thus enhancing the oxidation capacity in 
polluted regions, especially in winter, when the other photolytic $\mathrm{OH}$ sources are of minor importance. The results of the current study suggest that realistic HONO levels should be accounted for by global models and that simulated $\mathrm{HO}_{\mathrm{x}}$, $\mathrm{O}_{3}$ and secondary oxidation products should be revised accordingly.

Acknowledgements. The authors would like to thank J. Kleffmann, S. Dusanter, X. Ren and M Sörgel for kindly supplying their measurement data for their measurement campaigns namely, Santiago de Chile (2009), MCMA-2006, New York and DOMINO, respectively. The research leading to these results has received funding from the European Research Council under the European Union's Seventh Framework Programme (FP7/2007-2013)/ERC grant agreement no. 226144.

The service charges for this open access publication have been covered by the Max Planck Society.

Edited by: F. Dentener

\section{References}

Acker, K., Möller, D., Wieprecht, W., Meixner, F. X., Bohn, B., Gilge, S., Plass-Dülmer, C., and Berresheim, H.: Strong Daytime Production of $\mathrm{OH}$ from $\mathrm{HNO}_{2}$ at a Rural Mountain Site, Geophys. Res. Lett., 33, L02809, doi:10.1029/2005GL024643, 2006.

Alicke, B., Platt, U., and Stutz, J.: Impact of nitrous acid photolysis on the total hydroxyl radical budget during the Limitation of Oxidant Production/Pianura Padana Produzione di Ozono study in Milan, J. Geophys. Res., 107, 8196, doi:10.1029/2000JD000075, 2002.

Alicke, B., Geyer, A., Hofzumahaus, A., Holland, F., Konrad, S., Pätz, H. W., Schäfer, J., Stutz, J., Volz-Thomas, A. and Platt, U.: $\mathrm{OH}$ formation by HONO photolysis during the BERLIOZ experiment, J. Geophys. Res., 108, 8247, doi:10.1029/2001JD000579, 2003.

Atkinson, R., Baulch, D. L., Cox, R. A., Crowley, J. N., Hampson, R. F., Hynes, R. G., Jenkin, M. E., Rossi, M. J., and Troe, J.: Evaluated kinetic and photochemical data for atmospheric chemistry: Volume I - gas phase reactions of $\mathrm{Ox}, \mathrm{HO}_{\mathrm{x}}, \mathrm{NO}_{\mathrm{x}}$ and $\mathrm{SO}_{\mathrm{x}}$ species, Atmos. Chem. Phys., 4, 1461-1738, doi:10.5194/acp-41461-2004, 2004.

Aumont, B., Chervier, F., and Laval, S.: Contribution of HONO sources to the $\mathrm{NO}_{\mathrm{x}} / \mathrm{HO}_{\mathrm{x}} / \mathrm{O}_{3}$ chemistry in the polluted boundary layer, Atmos. Environ., 37, 487-498, 2003.

Bejan, I., Abd El Aal, Y., Barnes, I., Benter, T., Bohn, B., Wiesen, P., and Kleffmann, J.: The Photolysis of Ortho-Nitrophenols: A new Gas Phase Source of HONO, Phys. Chem. Chem. Phys., 8, 2028-2035, doi:10.1039/b516590c, 2006.

Brühl, C., Lelieveld, J., Crutzen, P. J., and Tost, H.: The role of carbonyl sulphide as a source of stratospheric sulphate aerosol and its impact on climate, Atmos. Chem. Phys., 12, 1239-1253, doi:10.5194/acp-12-1239-2012, 2012.

Clapp, L. J. and Jenkin, M.: Analysis of the relationship between ambient levels of $\mathrm{O}_{3}, \mathrm{NO}_{2}$ and $\mathrm{NO}$ as a function of $\mathrm{NO}_{\mathrm{x}}$ in the UK, Atmos. Environ., 35, 6391-6405, 2001.
Czader, B. H., Rappenglück, B., Percell, P., Byun, D. W., Ngan, F., and Kim, S.: Modeling nitrous acid and its impact on ozone and hydroxyl radical during the Texas Air Quality Study 2006, Atmos. Chem. Phys., 12, 6939-6951, doi:10.5194/acp-12-69392012, 2012.

Dusanter, S., Vimal, D., Stevens, P. S., Volkamer, R., Molina, L. T., Baker, A., Meinardi, S., Blake, D., Sheehy, P., Merten, A., Zhang, R., Zheng, J., Fortner, E. C., Junkermann, W., Dubey, M., Rahn, T., Eichinger, B., Lewandowski, P., Prueger, J., and Holder, $\mathrm{H}$.: Measurements of $\mathrm{OH}$ and $\mathrm{HO} 2$ concentrations during the MCMA-2006 field campaign - Part 2: Model comparison and radical budget, Atmos. Chem. Phys., 9, 6655-6675, doi:10.5194/acp-9-6655-2009, 2009.

Elshorbany, Y. F., Kurtenbach, R., Wiesen, P., Lissi, E., Rubio, M., Villena, G., Gramsch, E., Rickard, A. R., Pilling, M. J., and Kleffmann, J.: Oxidation capacity of the city air of Santiago, Chile, Atmos. Chem. Phys., 9, 2257-2273, doi:10.5194/acp-92257-2009, 2009a.

Elshorbany, Y. F., Kleffmann, J., Kurtenbach, R., Rubio, M., Lissi, E., Villena, G., Gramsch, E., Rickard, A. R., Pilling, M. J., and Wiesen, P.: Summertime photochemical ozone formation in Santiago, Chile, Atmos. Environ., 43, 6398-6407 doi:10.1016/j.atmosenv.2009.08.047, 2009b.

Elshorbany, Y. F., Kleffmann, J., Kurtenbach, R., Lissi, E., Rubio, M., Villena, G., Gramsch, E., Rickard, A. R., Pilling, M. J., and Wiesen, P.: Seasonal dependence of the oxidation capacity of the city of Santiago de Chile, Atmos. Environ., 44, 5383-5394, doi:10.1016/j.atmosenv.2009.08.036, 2010a.

Elshorbany, Y. F., Barnes, I., Becker, K. H., Kleffmann, J., and Wiesen, P.: Sources and Cycling of Tropospheric Hydroxyl Radicals - An Overview, Z. Phys. Chem., 224, 967-987, 2010b.

Elshorbany, Y. F., Kleffmann, J., Hofzumahaus, A., Kurtenbach, R., Wiesen, P., Dorn,H.-P., Schlosser, E., Brauers, T., Fuchs, H., Rohrer, F., Wahner, A., Kanaya, Y., Yoshino, A., Nishida, S., Kajii, Y., Martinez, M., Rudolf, M., Harder, H., Lelieveld, J., , Elste, T., Plass-Dülmer, C., Stange, G., and Berresheim, H.: $\mathrm{HO}_{\mathrm{x}}$ Budgets during HOxComp: a Case Study of $\mathrm{HO}_{\mathrm{x}}$ Chemistry under $\mathrm{NO}_{\mathrm{x}}$ limited Conditions, J. Geoophys. Res., 117, D03307, doi:10.1029/2011JD017008, 2012.

Febo, A., Perrino, C., and Allegrini, I.: Measurement of Nitrous Acid in Milan, Italy, by DOAS and Diffusion Denuders, Atmos. Environ., 30, 3599-3609, 1996.

Febo, A., Perrino, C., Bruno, P., and Mazziotti C.: FORMONA final report to the European Commission, Consiglio Nationale delle Ricerche, Rome, 1999.

Fortuin, J. P. F. and Kelder, H.: An ozone climatology based on ozonesonde and satellite measurements, J. Geophys. Res., 103, 31709-31734, 1998.

Goncąlves, M., Dabdub, D., Chang, W. L., Jorba, O., and Baldasano, J. M.: Impact of HONO sources on the performance of mesoscale air quality models, Atmos. Environ., 54, 168-176, doi:10.1016/j.atmosenv.2012.02.079, 2012.

Harris, G. W., Carter,W. P. L.,Winer, A. M., Pitts Jr., J. N., Platt, U., and Perner, D.: Observation of nitrous acid in the Los Angeles atmosphere and implications for predictions of ozone-precursor relationships, Environ. Sci. Technol., 16, 414-419, 1982.

Heland, J., Kleffmann, J., Kurtenbach, R., and Wiesen, P.: A New Instrument to Measure Gaseous Nitrous Acid (HONO) in the Atmosphere, Environ. Sci. Technol., 35, 3207-3212, 2001. 
Huang, G., Zhou, X., Deng, G., Qiao, H., and Civerolo, K.: Measurements of atmospheric nitrous acid and nitric acid, Atmos. Environ., 36, 2225-2235, 2002.

Jöckel, P., Sander, R., Kerkweg, A., Tost, H., and Lelieveld, J.: Technical Note: The Modular Earth Submodel System (MESSy) - a new approach towards Earth System Modeling, Atmos. Chem. Phys., 5, 433-444, doi:10.5194/acp-5-433-2005, 2005.

Jöckel, P., Tost, H., Pozzer, A., Brühl, C., Buchholz, J., Ganzeveld, L., Hoor, P., Kerkweg, A., Lawrence, M. G., Sander, R., Steil, B., Stiller, G., Tanarhte, M., Taraborrelli, D., van Aardenne, J., and Lelieveld, J.: The atmospheric chemistry general circulation model ECHAM5/MESSy1: consistent simulation of ozone from the surface to the mesosphere, Atmos. Chem. Phys., 6, 5067-5104, doi:10.5194/acp-6-5067-2006, 2006.

Jorba, O., Dabdub, D., Blaszczak-Boxe, C., Perez, C., Janjic, Z., Baldasano, J. M., Spada, M., Badia, A., Goncalves, M.: Potential Significance of Photoexcited $\mathrm{NO}_{2}$ on Global Air Quality with the NMMB/BSC Chemical Transport Model, J. Geophys. Res., 117, D13301, doi:10.1029/2012JD017730, 2012.

Kerkweg, A., Sander, R., Tost, H., and Jöckel, P.: Technical note: Implementation of prescribed (OFFLEM), calculated (ONLEM), and pseudo-emissions (TNUDGE) of chemical species in the Modular Earth Submodel System (MESSy), Atmos. Chem. Phys., 6, 3603-3609, doi:10.5194/acp-6-3603-2006, 2006.

Kleffmann, J., Heland, J., Kurtenbach, R., Lörzer, J. C., and Wiesen, P.: A New Instrument (LOPAP) for the Detection of Nitrous Acid (HONO), Environ. Sci. Technol., 9, 48-54, 2002.

Kleffmann, J., Kurtenbach, R., Lörzer, J. C., Wiesen, P., Kalthoff, N., Vogel, B., and Vogel, H.: Measured and simulated vertical profiles of nitrous acid Part I: Field measurements, Atmos. Environ., 37, 2949-2955, 2003.

Kleffmann, J., Gavriloaiei, T., Hofzumahaus, A., Holland, F., Koppmann, R., Rupp, L., Schlosser, E., Siese, M., and Wahner, A.: Daytime Formation of Nitrous Acid: A Major Source of OH Radicals in a Forest, Geophys. Res. Lett., 32, L05818, doi:10.1029/2005GL022524, 2005.

Kleffmann, J., Lörzer, J. C., Wiesen, P., Kern, C., Trick, S., Volkamer, R., Rodenas, M., and Wirtz, K.: Intercomparisons of the DOAS and LOPAP Techniques for the Detection of Nitrous Acid (HONO) in the Atmosphere, Atmos. Environ., 40, 3640-3652, 2006.

Kleffmann, J.: Daytime Sources of Nitrous Acid (HONO) in the Atmospheric Boundary Layer, Chem. Phys. Chem., 8, 1137-1144, 2007.

Kleffmann, J. and Wiesen, P.: Technical Note: Quantification of Interferences of Wet Chemical HONO LOPAP Measurements under Simulated Polar Conditions, Atmos. Chem. Phys., 8, 68136822, doi:10.5194/acp-8-6813-2008, 2008.

Kulmala, M. and Petäjä T.: Soil nitrites influence atmospheric chemistry, Science, 333, 1586-1587, doi:10.1126/science.1211872, 2011.

Kurtenbach, R., Becker, K. H., Gomes, J. A. G., Kleffmann, J., Lörzer, J. C., Spittler, M., Wiesen, P., Ackermann, R., Geyer, A., and Platt, U.: Investigation of Emissions and Heterogeneous Formation of HONO in a Road Traffic Tunnel, Atmos. Environ., 35, 3385-3394, 2001.

Lelieveld, J., Peters, W., Dentener F. J., and Krol, M. C.: Stability of tropospheric hydroxyl chemistry, J. Geophys. Res., 107, 4715,
doi:10.1029/2002JD002272, 2002.

Lelieveld, J., Brühl, C., Jöckel, P., Steil, B., Crutzen, P. J., Fischer, H., Giorgetta, M. A., Hoor, P., Lawrence, M. G., Sausen, R., and Tost, H.: Stratospheric dryness: model simulations and satellite observations, Atmos. Chem. Phys., 7, 1313-1332, doi:10.5194/acp-7-1313-2007, 2007.

Li, G., Lei, W., Zavala, M., Volkamer, R., Dusanter, S., Stevens, P., and Molina, L. T.: Impacts of HONO sources on the photochemistry in Mexico City during the MCMA-2006/MILAGO Campaign, Atmos. Chem. Phys., 10, 6551-6567, doi:10.5194/acp-106551-2010, 2010.

Li, S., Matthews, J., and Sinha, A.: Atmospheric Hydroxyl Radical Production from Electronically Excited $\mathrm{NO}_{2}$ and $\mathrm{H}_{2} \mathrm{O}$, Science, 319, 1657-1660, 2008.

Li, X., Brauers, T., Häseler, R., Bohn, B., Fuchs, H., Hofzumahaus, A., Holland, F., Lou, S., Lu, K. D., Rohrer, F., Hu, M., Zeng, L. M., Zhang, Y. H., Garland, R. M., Su, H., Nowak, A., Wiedensohler, A., Takegawa, N., Shao, M., and Wahner, A.: Exploring the atmospheric chemistry of nitrous acid (HONO) at a rural site in Southern China, Atmos. Chem. Phys., 12, 14971513, doi:10.5194/acp-12-1497-2012, 2012.

Li, Y., An, J., Min, M., Zhang, W., Wang, F., and Xie, P.: Impacts of HONO sources on the air quality in Beijing, Tianjin and Hebei province of china, Atmos. Environ., 45, 4735-4744, doi:10.1016/j.atmosenv.2011.04.086, 2011.

Lu, K., Zhang, Y., Su, H., Brauers, T., Chou, C. C., Hofzumahaus, A., Liu, S. C., Kita, K., Kondo, Y., Shao, M., Wahner, A., Wang, J., Wang, X., and Zhu, T.: Oxidant $\left(\mathrm{O}_{3}+\mathrm{NO}_{2}\right)$ production processes and formation regimes in Beijing, J. Geophys. Res., 115, D07303, doi:10.1029/2009JD012714, 2010.

New York State Department of Environmental Conservation, 2005 ozone exceedences in New York State, http://www.dec.ny.gov/ docs/air_pdf/05o3exc.pdf, (last access: 22 May 2012), 2006.

Ndour, M., D’Anna, B., George, C., Ka, O., Balkanski, Y., Kleffmann, J., Stemmler, K., and Ammann, M.: Photoenhanced uptake of $\mathrm{NO}_{2}$ on mineral dust: Laboratory experiments and model simulations, Geophys. Res. Lett., 35, L05812, doi:10.1029/2007GL032006, 2008.

Ortega, J., Helmig, D., Guenther, A., Harley, P., Pressley, S., and Vogel, C.: Flux estimates and $\mathrm{OH}$ reaction potential of reactive biogenic volatile compounds (BVOCs) from a mixed northern hardwood forest, Atmos. Environ., 41, 5479-5495, 2007.

Perner, D. and Platt, U.: Detection of Nitrous Acid in the Atmosphere by Differential Optical Absorption, J. Geophys. Res., 6, 917-920, 1979.

Platt, U. and Perner, D.: Direct Measurements of Atmospheric $\mathrm{CH}_{2} \mathrm{O}, \mathrm{HNO}_{2}, \mathrm{O}_{3}, \mathrm{NO}_{2}$, and $\mathrm{SO}_{2}$ by Differential Optical Absorption in the Near UV, J. Geophys. Res., 85, 7453-7458, 1980.

Pöschl, U., von Kuhlmann, R., Poisson, N., and Crutzen, P. J.: Development and intercomparison of condensed isoprene oxidation mechanisms for global atmospheric modeling, J. Atmos. Chem., 37, 29-52, 2000.

Pozzer, A., Jöckel, P., Tost, H., Sander, R., Ganzeveld, L., Kerkweg A., and Lelieveld, J.: Simulating organic species with the global atmospheric chemistry general circulation model ECHAM5/MESSy1: a comparison of model results with observations, Atmos. Chem. Phys., 7, 2527-2550, doi:10.5194/acp-72527-2007, 2007. 
Pozzer, A., Pollmann, J., Taraborrelli, D., Jöckel, P., Helmig, D., Tans, P., Hueber J., and Lelieveld, J.: Observed and simulated global distribution and budget of atmospheric $\mathrm{C}_{2}-\mathrm{C}_{5}$ alkanes, Atmos. Chem. Phys., 10, 4403-4422, doi:10.5194/acp-10-44032010, 2010.

Pozzer, A., de Meij, A., Pringle, K. J., Tost, H., Doering, U. M., van Aardenne, J., and Lelieveld, J.: Distributions and regional budgets of aerosols and their precursors simulated with the EMAC chemistry-climate model, Atmos. Chem. Phys., 12, 961-987, doi:10.5194/acp-12-961-2012, 2012.

Ren, X., Harder, H., Martinez, M., Lesher, R. L., Oliger, A., Simpas, J. B., Brune, W. H., Schwab, J. J., Demerjian, K. L., He, Y., Zhou, X., and Gao, $\mathrm{H}$.: $\mathrm{OH}$ and $\mathrm{HO}_{2}$ Chemistry in the Urban Atmosphere of New York City, Atmos. Environ., 37, 3639-3651, 2003.

Ren, X., Brune, W. H., Mao, J., Mitchell, M. J., Lesher, R. L., Simpas, J. B., Metcalf, A. R., Schwab, J.J., Cai, C., Li, Y., Demerjian, K. L., Felton, H. D., Boynton, G., Adams, A., Perry, J., He, Y., Zhou, X. and Hou, J.: Behavior of $\mathrm{OH}$ and $\mathrm{HO}_{2}$ in the Winter Atmosphere in New York City, Atmos. Environ., 40, Supplement 2, 252-263, 2006.

Ren, X., Gao, H., Zhou, X., Crounse, J. D., Wennberg, P. O., Browne, E. C., LaFranchi, B. W., Cohen, R. C., McKay, M., Goldstein, A. H., and Mao, J.: Measurement of atmospheric nitrous acid at Blodgett Forest during BEARPEX2007, Atmos. Chem. Phys., 10, 6283-6294, doi:10.5194/acp-10-6283-2010, 2010.

Roeckner, E., Brokopf, R., Esch, M., Giorgetta, M., Hagemann, S., Kornblueh, L., Manzini, E., Schlese, U., and Schulzweida, U.: Sensitivity of simulated climate to horizontal and vertical resolution in the ECHAM5 atmosphere model, J. Climate, 19, 37713791, 2006.

Sander, R., Kerkweg, A., Jöckel, P., and Lelieveld, J.: Technical note: The new comprehensive atmospheric chemistry module MECCA, Atmos. Chem. Phys. 5, 445-450, doi:10.5194/acp-5445-2005, 2005.

Sörgel, M., Regelin, E., Bozem, H., Diesch, J.-M., Drewnick, F., Fischer, H., Harder, H., Held, A., Hosaynali-Beygi, Z., Martinez, M., and Zetzsch, C.: Quantification of the unknown HONO daytime source and its relation to $\mathrm{NO}_{2}$, Atmos. Chem. Phys., 11, 10433-10447, doi:10.5194/acp-11-10433-2011, 2011a.

Sörgel, M., Trebs, I., Serafimovich, A., Moravek, A., Held, A., and Zetzsch, C.: Simultaneous HONO measurements in and above a forest canopy: influence of turbulent exchange on mixing ratio differences, Atmos. Chem. Phys., 11, 841-855, doi:10.5194/acp11-841-2011, 2011b.

Stemmler, K., Ammann, M., Dondors, C., Kleffmann, J., and George, C.: Photosensitized Reduction of Nitrogen Dioxide on Humic Acid as a Source of Nitrous Acid, Nature, 440, 195-198, doi:10.1038/nature04603, 2006.

Stemmler, K., Ndour, M., Elshorbany, Y., Kleffmann, J., D’Anna, B., George, C, Bohn, B., and Ammann, M.: Light induced conversion of nitrogen dioxide into nitrous acid on submicron humic acid aerosol, Atmos. Chem. Phys., 7, 4237-4248, doi:10.5194/acp-7-4237-2007, 2007.

Stutz, J., Alicke, B., and Neftel, A.: Nitrous Acid Formation in the Urban Atmosphere: Gradient Measurements of $\mathrm{NO}_{2}$ and HONO over Grass in Milan, Italy, J. Geophys. Res., 107, 8192, doi:10.1029/2001JD000390, 2002.
Su, H., Cheng, Y. F., Shao, M., Gao, D. F., Yu, Z. Y., Zeng, L. M., Slanina, J., Zhang, Y. H., and Wiedensohler, A.: Nitrous acid (HONO) and its daytime sources at a rural site during the 2004 PRIDE-PRD experiment in China, J. Geophys. Res., 113, D14312, doi:10.1029/2007JD009060, 2008.

Su, H., Cheng, Y., Oswald, R., Behrendt, T., Trebs, I., Meixner, F. X., Andreae, M. O., Cheng, P., Zhang, Y., and Pöschl, U.: Soil Nitrite as a Source of Atmospheric HONO and OH Radicals, Science, 333, 1616-1618, doi:10.1126/science.1207687, 2011.

Taraborrelli, D., Lawrence, M. G., Butler, T. M., Sander, R., and Lelieveld, J.: Mainz Isoprene Mechanism 2 (MIM2): an isoprene oxidation mechanism for regional and global atmospheric modelling, Atmos. Chem. Phys., 9, 2751-2777, doi:10.5194/acp-92751-2009, 2009.

Tost, H., Jöckel, P., Kerkweg, A., Pozzer, A., Sander, R., and Lelieveld, J.: Global cloud and precipitation chemistry and wet deposition: tropospheric model simulations with ECHAM5/MESSy1, Atmos. Chem. Phys., 7, 2733-2757, doi:10.5194/acp-7-2733-2007, 2007.

van Aalst, M. K., van den Broek, M. M. P., Bregman, A., Brühl, C., Steil, B., Toon, G. C., Garcelon, S., Hansford, G. M., Jones, R. L., Gardiner, T. D., Roelofs, G.-J., Lelieveld, J., and Crutzen, P. J.: Trace gas transport in the 1999/2000 Arctic; comparison of nudged GCM runs with observations, Atmos. Chem. Phys., 4, 81-93, doi:10.5194/acp-4-81-2004, 2004.

Veitel, H.: Vertical profiles of $\mathrm{NO}_{2}$ and $\mathrm{HONO}$ in the boundary layer, $\mathrm{PhD}$ Thesis, University of Heidelberg, http://archiv.ub.uni-heidelberg.de/volltextserver/volltexte/ 2002/2490/pdf/Diss Veitel2002.pdf, (last access: 22 May 2012), 2002.

Villena, G., Kleffmann, J, Kurtenbach, R., Wiesen, P., Lissi, E., Rubio, M. A., Croxatto, J., and Rappenglück, B., Vertical gradients of $\mathrm{HONO}, \mathrm{NO}_{\mathrm{x}}$ and $\mathrm{O}_{3}$ in Santiago de Chile, Atmos. Environ. 45, 3867-3873, 2011a.

Villena, G., Wiesen,P., Cantrell, C. A., Flocke, F., Fried, A., Hall, S. R., Hornbrook, R. S., Knapp, D., Kosciuch, E., Mauldin III, R. L., McGrath, J. A., Montzka, D., Richter, D., Ullmann, K., Walega, J., Weibring, P., Weinheimer, A., Staebler, R. M., Liao, J., Huey, L. G., and Kleffmann, J.: Nitrous acid (HONO) during polar spring in Barrow, Alaska: A net source of OH radicals?, J. Geophys. Res., 116, D00R07, doi:10.1029/2011JD016643, 2011b.

Vogel, B., Vogel, H., Kleffmann, J., and Kurtenbach, R.: Measured and Simulated Vertical Profiles of Nitrous Acid, Part II - Model Simulations and Indications for a Photolytic Source, Atmosph. Environ., 37, 2957-2966, 2003.

Volkamer, R., Sheehy, P., Molina, L. T., and Molina, M. J.: Oxidative capacity of the Mexico City atmosphere - Part 1: A radical source perspective, Atmos. Chem. Phys., 10, 6969-6991, doi:10.5194/acp-10-6969-2010, 2010.

von Kuhlmann, R., Lawrence, M. G., Pöschl, U., and Crutzen, P. J.: Sensitivities in global scale modeling of isoprene, Atmos. Chem. Phys., 4, 1-17, doi:10.5194/acp-4-1-2004, 2004.

Wong, K. W., Oh, H.-J., Lefer, B. L., Rappenglück, B., and Stutz, J.: Vertical profiles of nitrous acid in the nocturnal urban atmosphere of Houston, TX, Atmos. Chem. Phys., 11, 3595-3609, doi:10.5194/acp-11-3595-2011, 2011.

Wong, K. W., Tsai, C., Lefer, B., Haman, C., Grossberg, N., Brune, W. H., Ren, X., Luke, W., and Stutz, J.: Daytime HONO 
vertical gradients during SHARP 2009 in Houston, TX, Atmos. Chem. Phys., 12, 635-652, doi:10.5194/acp-12-635-2012, 2012.

Yu, Y., Galle, B., Panday, A., Hodson, E., Prinn, R., and Wang, S.: Observations of high rates of $\mathrm{NO}_{2}$-HONO conversion in the nocturnal atmospheric boundary layer in Kathmandu, Nepal, Atmos. Chem. Phys., 9, 6401-6415, doi:10.5194/acp-9-6401-2009, 2009.

Zhang, N., Zhou, X., Shepson, P. B., Gao, H., Alaghmand, M., and Stirm B.: Aircraft measurement of HONO vertical profiles over a forested region, Geophys. Res. Lett., 36, L15820, doi:10.1029/2009GL038999, 2009.

Zhang, R., Sarwar, G., Fung, J. C. H., Lau, A. K. H., and Zhang, Y.: Impact of nitrous acid chemistry on air quality modeling results over the Pearl River Delta region, Atmos. Chem. Phys. Discuss., 11, 15075-15117, doi:10.5194/acpd-11-15075-2011, 2011.

Zhang, N., Zhou, X., Bertman, S., Tang, D., Alaghmand, M., Shepson, P. B., and Carroll, M. A.: Measurements of ambient HONO concentrations and vertical HONO flux above a northern Michigan forest canopy, Atmos. Chem. Phys., 12, 8285-8296, doi:10.5194/acp-12-8285-2012, 2012.
Zhou, X., Gao, H., He, Y., Huang, G., Bertman, S. B., Civerolo, K., and Schwab, J.: Nitric Acid Photolysis on Surfaces in Low-NO Environments: Significant Atmospheric Implications, Geophys. Res. Lett., 30, 2217, doi:10.1029/2003GL018620, 2003.

Zhou, X., Zhang, N., TerAvest, M., Tang, D., Hou, J., and Bertman, S., Alaghmand, M., Shepson, P. B., Carroll, M. A., Griffith, S., Dusanter, S., Stevens, P. S.: Nitric acid photolysis on forest canopy surface as a source for tropospheric nitrous acid, Nature Geosci. Lett., 4, 440-443, doi:10.1038/ngeo1164, 2011.

Zhou, X., Civerolo, K., Dai, H., Huang, G., Schwab, J. J., and Demerjian, K. L.: Summertime nitrous acid chemistry in the atmospheric boundary layer at a rural site in New York State, J. Geophys. Res., 107, 4590, doi:10.1029/2001JD001539, 2002. 